
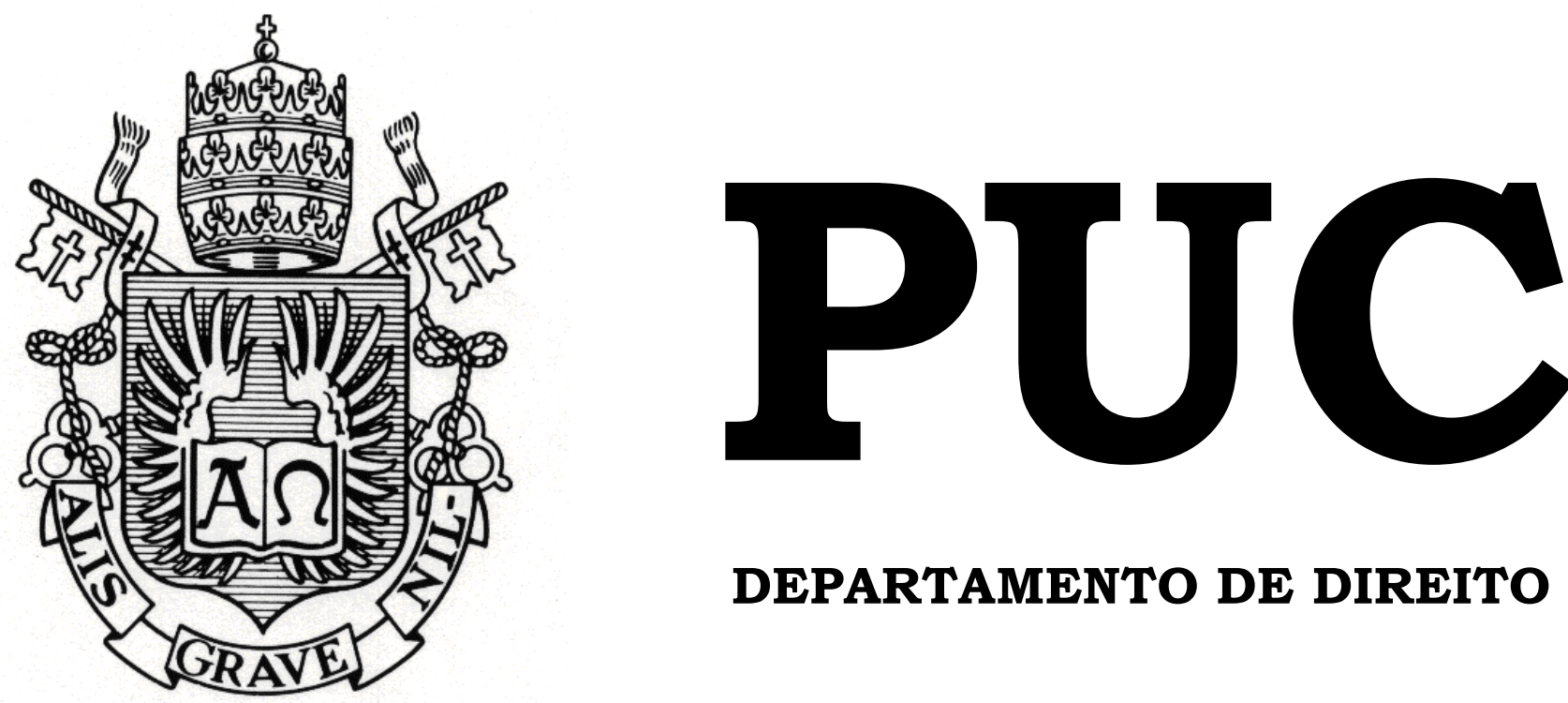

DEPARTAMENTO DE DIREITO

\title{
O DIREITO DE PREFERÊNCIA DO LOCATÁRIO DE IMÓVEL URBANO: OS LIMITES ENTRE O EXERCÍCIO REGULAR E O ABUSO DO DIREITO
}

por

ANTONIO VIGNOLI HOAGLAND SOARES

ORIENTADORA: Aline de Miranda Valverde Terra 2019.2

PONTIFÍCIA UNIVERSIDADE CATÓLICA DO RIO DE JANEIRO RUA MARQUÊS DE SÃO VICENTE, 225 - CEP 22451-900 RIO DE JANEIRO - BRASIL 


\section{O DIREITO DE PREFERÊNCIA DO LOCATÁRIO DE IMÓVEL URBANO: OS LIMITES ENTRE O EXERCÍCIO REGULAR E O ABUSO DO DIREITO}

por

\section{ANTONIO VIGNOLI HOAGLAND SOARES}

Monografia apresentada ao

Departamento de Direito da Pontifícia Universidade Católica do Rio de Janeiro (PUC-Rio) como requisito parcial para a obtenção do título de Bacharel em Direito.

Orientadora: Aline de Miranda Valverde Terra 


\section{AGRADECIMENTOS}

Antes de mais nada, agradeço ao meu pai, pelo amor e pelo apoio em cada etapa da minha formação, e à minha mãe, que se estivesse aqui hoje estaria muito feliz e orgulhosa de mim. Agradeço às minhas avós, Decy e Christina, que foram essenciais para que eu pudesse chegar até aqui; à minha tia, pelas boas experiências que compartilhamos e por todo o suporte que me deu ao longo dos anos; à minha irmã, pelo papel importante que teve na minha vida; à Patricia, pelos ensinamentos e lições de vida.

Ao Leo, agradeço pela amizade que construímos e por sempre me amparar nos momentos em que mais preciso, e à Cecília M., pelo carinho e pelos bons momentos que vivemos.

Também agradeço a todos os amigos que fiz ao longo desses cinco anos de PUC-Rio, em especial à Cecília R., Larissa, Carol e ao Antônio Pedro, tão especiais a mim, cada um à sua maneira.

A todos com quem trabalhei no Pinheiro Guimarães, meu primeiro escritório, agradeço pela experiência e pelo grande crescimento profissional que me propiciaram. Agradeço, sobretudo, à Luisa Cabral, por ser responsável por me introduzir ao meio do Direito Imobiliário e pelos ensinamentos que carrego comigo até hoje.

Agradeço, ainda, a todos com quem tenho a oportunidade de trabalhar no meu atual escritório, Terra, Tavares, Ferrari, Elias Rosa. Em especial ao Yuri e à Rafaela, pelo papel fundamental que desempenharam e desempenham na minha formação e pela grande admiração que tenho por eles; aos meus amigos de sala, Mateus, Antônia e Carol, pelos momentos de descontração e por tornar mais leves muitos dos meus fins de tarde; ao Sérgio, pelos ensinamentos e por ter despertado o meu interesse pelo tema desta monografia e me incentivado a escolhê-lo; e, ainda, ao Márcio, pelo apoio e por ter demonstrado tanto interesse no tema que será aqui tratado. 
Por fim, agradeço, em especial, à Aline, minha orientadora, que, desde as minhas primeiras semanas de faculdade, me inspirou como a profissional competente e atenciosa que é. Obrigado por ter tido um papel tão importante na minha trajetória até aqui e pelos importantes conselhos que já me deu. Nada mais simbólico do que ter te escolhido como orientadora para fechar este ciclo da graduação. 


\section{RESUMO}

O presente estudo investiga de que formas o direito de preferência conferido ao locatário de imóvel urbano pode vir a ser exercido de maneira irregular, configurando abuso do direito, bem como os possíveis meios de coibir o exercício abusivo desse direito. Para tanto, inicialmente, é feita uma análise da forma que o direito de preferência é previsto pela Lei de Locações e as suas peculiaridades, em especial a finalidade a que se destina, os seus pressupostos e o procedimento que deve ser observado para que o direito possa ser exercido - que, caso não observado, pode fazer com que a relação prelatícia entre em uma fase patológica. Após, o instituto do abuso do direito é analisado desde as suas origens até a sua previsão pelo Código Civil de 2002. Assim, à luz dos elementos estudados, será tratado do abuso do direito de preferência do locatário, que constitui mais uma forma pela qual a relação prelatícia pode ser acometida por um viés patológico, tratando-se de algumas das possíveis formas pelas quais esse abuso pode vir a ocorrer, assim como de alguns dos meios de coibi-lo.

Palavras-chave: Direito Civil; Direito Imobiliário; Lei de Locações; Direito de preferência; Relação prelatícia; Abuso do direito; Fim econômico ou social; Boa-fé objetiva; Bons costumes. 


\section{SUMÁRIO}

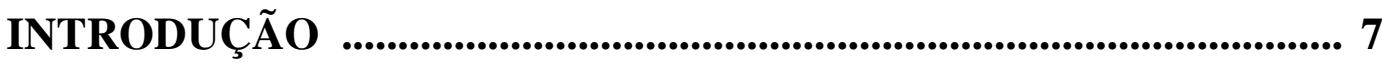

CAPÍTULO 1 - O DIREITO DE PREFERÊNCIA DO LOCATÁRIO

DE IMÓVEL URBANO .................................................................................... 11

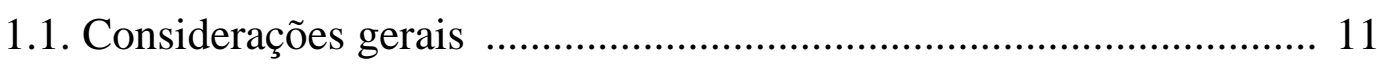

1.2. A finalidade do direito de preferência da Lei de Locações: a preservação dos laços desenvolvidos pelo locatário com o imóvel locado..................... 13

1.3. Pressupostos para o exercício do direito ………………………….... 15

1.4. O procedimento para o exercício do direito ....................................... 18

1.5. A fase patológica da relação de preferência ........................................ 21

CAPÍTULO 2 - O ABUSO DO DIREITO NA PERSPECTIVA

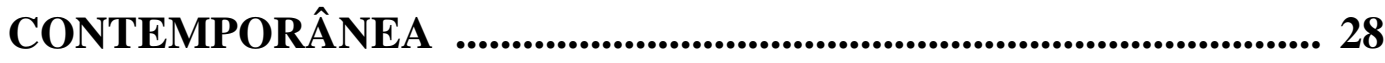

2.1. Origens e definição ........................................................................ 28

2.2. A objetivação do abuso do direito no Código Civil de 2002 e a sua configuração como categoria autônoma que se aplica à todas as situações

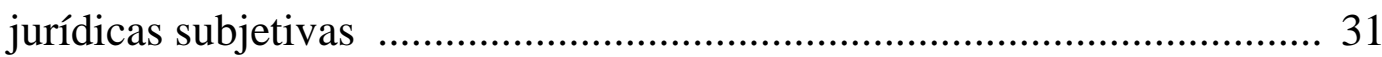

2.3. Critérios de aferição do abuso do direito no artigo 187 do Código Civil

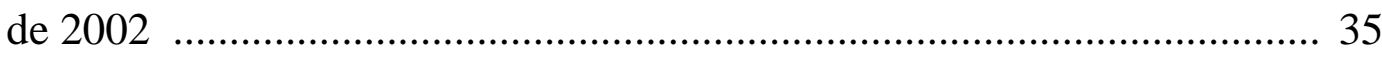

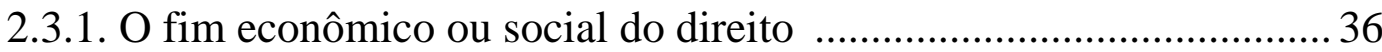

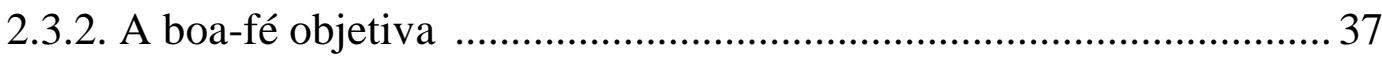

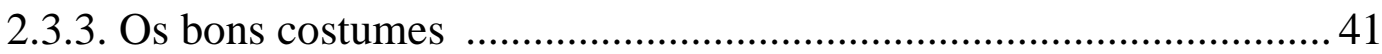

2.4. As consequências do ato abusivo ........................................................ 44

CAPÍTULO 3 - O EXERCÍCIO ABUSIVO DO DIREITO DE PREFERÊNCIA DO LOCATÁRIO ......................................................... 48

3.1. As possíveis formas de o locatário exercer abusivamente o seu direito de preferência 49

3.2. Os possíveis meios de coibir o exercício abusivo do direito de preferência

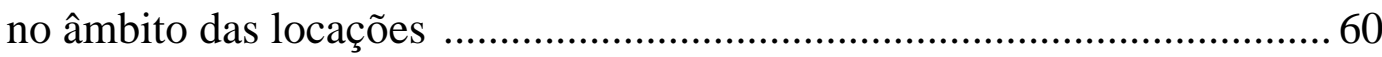

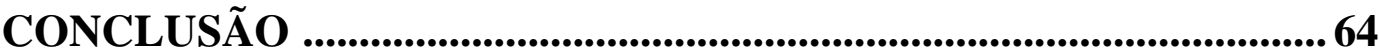

REFERÊNCIAS BIBLIOGRÁFICAS .....................................................66 


\section{LISTA DE ABREVIAÇÕES}

A.I. - Agravo de Instrumento

Ap. Cív. - Apelação Cível

Art. - Artigo

Arts. - Artigos

C.C. - Câmara Cível

CC - Código Civil

C.D.P. - Câmara de Direito Privado

Des. - Desembargador

EREsp - Embargos de Divergência em Recurso Especial

Min. - Ministro

Proc. - Processo

Rel. - Relator

REsp - Recurso Especial

STJ - Superior Tribunal de Justiça

STJ de Portugal - Supremo Tribunal de Justiça de Portugal

TJRJ - Tribunal de Justiça do Rio de Janeiro

TJSP - Tribunal de Justiça de São Paulo

V.g. - Verbi gratia 


\section{INTRODUÇÃO}

No meio imobiliário, uma das muitas cautelas que devem ser tomadas antes de se proceder com a compra de um imóvel é verificar se há em vigor um contrato de locação e, o havendo - em especial se este estiver averbado junto à matrícula do imóvel -, se foi dado ao locatário a oportunidade de exercer o seu direito de preferência na compra daquele imóvel.

Caso a alienação do bem seja efetivada sem que assim seja procedido, daí podem advir graves consequências, já que, a depender do caso, o negócio poderá ser reputado sem efeito perante o locatário, de modo que este poderá adjudicar compulsoriamente o imóvel, desde que deposite o valor pelo qual tenha sido procedida a venda, acrescido das demais despesas incorridas com a operação. ${ }^{1}$

Em Portugal, país onde a legislação prevê uma massiva quantidade de hipóteses de direito de preferência, o tema é objeto de amplo estudo e a doutrina levanta severas críticas ao instituto, em sua maioria quanto aos entraves que vem a causar especialmente ao mercado imobiliário. Nesse sentido, ANTÓNIO MENEZES CORDEIRO adverte que "não sendo um factor de progresso, a multiplicação das preferências representa um enorme desperdício de riqueza, com o qual se deve saber lidar, para minorar os seus aspectos negativos".2

Diante dessa advertência, buscar-se-á, portanto, entender de que forma se dá o direito de preferência no âmbito das relações locatícias e as razões que nortearam a sua previsão legal.

Nesse sentido, é importante ter em mente que o direito em questão tem em si consubstanciado uma finalidade social e econômica, de preservar os laços que o locatário desenvolveu com o imóvel a ele locado, que é o que

\footnotetext{
${ }^{1}$ SANTOS, Gildo dos. Locação e despejo: comentários à Lei 8.245/91. 7. ed. rev., ampl. e atual. São Paulo: Revista dos Tribunais, 2011, p. 222.

${ }^{2}$ CORDEIRO, António Menezes. Tratado de Direito Civil Português, v. II, tomo II. Coimbra: Almeida, 2010, p. 485.
} 
justifica a sua consagração pelo ordenamento. Foi tendo em vista este interesse que o legislador entendeu ser justificável limitar a liberdade contratual do locador, impondo a obrigação de que este, uma vez decidindo alienar o imóvel, conceda ao locatário a preferência para adquiri-lo, em igualdade de condições com terceiros.

No entanto, apesar da indiscutível relevância do direito de preferência conferido ao locatário, por se tratar de um direito de prelação previsto pela lei, e não pela vontade das partes, deve este ser interpretado restritivamente, visando sempre cumprir a finalidade que o legislador o conferiu ao instituílo e não para fins diversos desta, de modo a evitar uma injustificada limitação na esfera jurídica do locador.

Diante desse cenário, o presente estudo visa analisar o direito de preferência do locatário sob um viés ainda muito pouco explorado, qual seja, o do seu exercício de forma irregular, que constitui um abuso desse direito.

$\mathrm{O}$ instituto do abuso do direito "surgiu justamente no intuito de reprimir os atos que, embora praticados com estrita observância da lei, violavam o seu espírito", ${ }^{3}$ de modo que "abusa do direito quem o exerce de forma aparentemente regular, mas em contradição com os valores que o ordenamento pretende por meio dele realizar", 4 tais valores não são apenas aqueles pretendidos pela finalidade do direito, mas também pela boa-fé objetiva e pelos bons costumes.

É, portanto, justamente sob essa perspectiva que será procedido o presente estudo, de modo a entender de que formas o locatário pode vir a exercer o seu direito de forma abusiva, excedendo os limites que definem o seu exercício regular.

\footnotetext{
${ }^{3}$ TEPEDINO, Gustavo, BARBOZA, Heloisa Helena; MORAES, Maria Celina Bodin de (Coord.). Código Civil interpretado conforme a Constituição da República. v. 1. 3. ed. rev. e ampl. Rio de Janeiro: Renovar, 2014, p. 345.

${ }^{4}$ SCHREIBER, Anderson. A proibição de comportamento contraditório: tutela da confiança e venire contra factum proprium. 4. ed. rev. e atual. São Paulo: Atlas, 2016, p. 75.
} 
Nos dizeres de Sylvio CAPANEMA DE SouZA, co-autor da atual Lei de Locações, essa seria "uma nova perspectiva do direito de preferência, que ainda não foi enfrentada pela doutrina". ${ }^{5}$

A referida afirmação se deu em um parecer jurídico no qual o autor tratou do assunto no âmbito de um emblemático caso que envolveu uma disputa de 180 milhões de reais pelo imóvel de um luxuoso hotel na Avenida Atlântica, no Rio de Janeiro, e que contou com mais quatro pareceres jurídicos dos mais importantes juristas brasileiros. Tal fato apenas corrobora a relevância do tema que será aqui tratado.

O presente estudo pretende, portanto, definir algumas das formas pelas quais o exercício do direito de preferência do locatário é tomado por um caráter abusivo, o qual o ordenamento jurídico deve coibir, sem, no entanto, ter a intenção de esgotar o tema, mas sim de fomentar a sua discussão.

Para tanto, no primeiro capítulo, será realizada uma análise do direito de preferência que é previsto pela Lei $\mathrm{n}^{\circ}$ 8.245/1991, tratando-se das suas peculiaridades, em especial a finalidade a que se destina, os pressupostos necessários para o seu exercício e o procedimento definido pela lei que deve ser observado para que o direito possa ser exercido pelo locatário, que, caso não observado, pode fazer com que a relação prelatícia entre em uma fase patológica, que se dá, a princípio, por consequência de atos do locador.

No segundo capítulo, por sua vez, examinar-se-á a teoria do abuso do direito, analisando, primeiramente, as suas origens e a definição do instituto e, posteriormente, a objetivação da figura do abuso do direito no Código Civil de 2002 e a sua configuração como uma categoria autônoma aplicável a qualquer situação jurídica subjetiva. Assim, analisar-se-á, de forma detida, cada um dos três critérios de aferição do abuso previstos no artigo 187 do Código Civil, bem como as consequências que podem advir da configuração do ato abusivo.

\footnotetext{
${ }^{5}$ SOUZA, Sylvio Capanema de. Parecer jurídico elaborado por solicitação da consulente BHG S/A - Brazil Hospitality Group, juntado ao processo no 0000564-57.2012.8.19.000. Rio de janeiro, 6 de janeiro de 2012. p. 41.
} 
Já no terceiro capítulo, será tratada de uma outra forma pela qual a relação prelatícia pode ser acometida por um viés patológico, não tratada no primeiro capítulo, que se dá precisamente quando o locatário exerce o seu direito de preferência de maneira abusiva. Dessa forma, tratar-se-á de algumas das possíveis formas pelas quais esse abuso pode vir a ocorrer, assim como dos possíveis meios de coibi-lo, para que então, finalmente, sejam elencadas as conclusões deste trabalho. 


\section{CAPÍTULO 1 - O DIREITO DE PREFERÊNCIA DO LOCATÁRIO DE IMÓVEL URBANO}

\subsection{Considerações gerais}

No âmbito do Direito, é dito que há preferência ou que há a obrigação de dar preferência quando um sujeito (o obrigado ou sujeito passivo da relação de preferência), na hipótese de querer celebrar certo negócio (o negócio preferível), tenha a obrigação de o fazer com uma pessoa determinada (o preferente), desde que esta aceite as exatas condições do negócio em causa (tanto por tanto), e isso em detrimento de um terceiro, com o qual aquele negócio fora previamente ajustado. ${ }^{6}$

Em linhas gerais, pode ser entendido como o direito de ter preferência na celebração de certo contrato, com exclusão de qualquer outro interessado, desde que ofereça as mesmas condições propostas. ${ }^{7}$

Sendo assim, o obrigado a dar a preferência conserva a sua liberdade de contratar ou não contratar. Porém, uma vez que tome a decisão de celebrar aquele contrato, fica ele obrigado a escolher o preferente como contraparte desse contrato projetado - desde que ofereça tanto por tanto -, de modo que a sua liberdade contratual sofre, portanto, uma limitação neste ponto. ${ }^{8}$

Esse direito, também conhecido como de prelação ou de preempção, pode ser convencional, quando tiver origem na convenção entre as partes, ou legal, quando derivar da lei. O primeiro pode surgir como um contrato autônomo ou como cláusula acessória de outro contrato. Por outro lado, o segundo, se dá quando o legislador, no Código Civil e em legislação

\footnotetext{
${ }^{6}$ CORDEIRO, António Menezes. Tratado de Direito Civil Português, v. II, tomo II. p. 462.

${ }^{7}$ SCHREIBER, Anderson. Manual de direito civil contemporâneo. São Paulo: Saraiva, 2018, p. 516.

${ }^{8}$ GUEDES, Agostinho Cardoso. O Exercício do Direito de Preferência. Teses. Porto: Publicações Universidade Católica, 2006, p. 85.
} 
extravagante, prevê tal direito e o associa a diversas situações jurídicas, ${ }^{9}$ quando há o reconhecimento de interesses dignos de uma maior proteção. ${ }^{10}$

Uma importante consequência da distinta origem dos direitos de preferência legais e dos convencionais se dá no tocante à interpretação que deles deve ser feita.

Tratando-se de pacto de preferência, o intérprete deverá averiguar a vontade das partes ao estabelecerem o direito para que possa delimitar a sua abrangência. ${ }^{11}$ Já as preferências legais, nos quais se estabelece uma vinculação heterônoma entre o preferente e o obrigado à preferência - que não decorre, portanto, da autonomia destes -, possuem uma natureza excepcional, visto que redundam em uma verdadeira limitação da liberdade de contratar no que diz respeito à escolha da contraparte, o que "obriga, pelo menos, a uma atitude de cautela na definição das obrigações impostas ao sujeito passivo". ${ }^{12}$

Quanto aos direitos de preferência legais deve-se destacar que são os mais diversos, sendo alguns exemplos os conferidos: aos condôminos de bens indivisíveis (artigo 504 do Código Civil); aos superficiários e aos proprietários do solo (artigo 1.373 do Código Civil); aos coerdeiros (artigo 1.794 do Código Civil); aos acionistas de sociedade anônima controladora de sociedade subsidiária integral (artigo 253, inciso I, da Lei nº 6.404/1976Lei das Sociedades por Ações); aos Municípios (artigo 25 e seguintes da Lei $\mathrm{n}^{\circ} 10.257 / 2001$ - Estatuto da Cidade); aos arrendatários rurais (artigo 92, §§ $3^{\circ}$ e $4^{\circ}$, da Lei $n^{\circ} 4.504 / 1964$ - Estatuto da Terra); e aos locatários - aí englobados também os sublocatários - de imóveis urbanos residenciais ou comerciais (artigo 27 e seguintes da Lei no 8.245/1991 - Lei de Locações).

Este último é o direito do qual ocupa-se o presente estudo. $\mathrm{O}$ direito de preferência do locatário, como visto, encontra previsão na Lei $\mathrm{n}^{\circ}$

\footnotetext{
${ }^{9}$ LGOW, Carla Wainer Charléo. Direito de Preferência. São Paulo: Atlas, 2013, p. 6-7.

${ }^{10}$ BUFULIN, Augusto Passamani. Breves notas sobre o direito de preferência na locação de imóveis urbanos: Lei 8.245/1991. Revista de Direito Privado, São Paulo, v. 14, n. 53, p. 101-120., jan./mar. 2013, p. 104.

${ }^{11}$ LGOW, Carla Wainer Charléo. Direito de Preferência. p. 29.

12 GUEDES, Agostinho Cardoso. O Exercício do Direito de Preferência. p. 104-106.
} 
8.245/1991, que prevê o regime especial das locações urbanas, e é por ela regulado, mas, no que esta "for omissa, aplicam-se os princípios tradicionais da preempção"13 - que se encontram previstos nos artigos 513 a 520 do Código Civil.

\subsection{A finalidade do direito de preferência da Lei de Locações: a preservação dos laços desenvolvidos pelo locatário com o imóvel locado}

A Lei $n^{\circ} 8.245 / 1991$, segundo CAIO Mário da Silva Pereira, tem como um de seus pontos cardeais a "fixação do locatário no imóvel". ${ }^{14}$ Com isso, ao instituir nessa lei o direito de preferência, o legislador teve uma marcante preocupação, de índole social e econômica, de preservar os laços desenvolvidos pelo locatário com o imóvel locado, já que, dessa forma, seria possível um melhor desempenho da função social da propriedade. ${ }^{15}$

Com efeito, foi em virtude desse interesse que o legislador considerou que seria por bem justificável limitar a liberdade contratual do locador, impondo a obrigação de que este, uma vez decidindo alienar o imóvel, conceda ao locatário a preferência para adquiri-lo, em igualdade de condições com terceiros.

A propósito, SYlvio CAPANEMA DE SOUZA, co-autor do projeto de lei da Lei ${ }^{\circ}$ 8.245/1991, pontua que a finalidade do direito de preferência que esta prevê em seu artigo 27 é "a de manter o locatário na posse do imóvel, seja para lhe garantir a moradia ou para continuar a exercer o seu comércio", evitando, assim, que a alienação importe em eventual despejo do locatário, ${ }^{16}$ fazendo com que este, "que até então só exercia a posse direta, se converta

\footnotetext{
${ }^{13}$ VENOSA, Sílvio de Salvo. Direito Civil: Contratos em Espécie. 13. ed. São Paulo: Atlas, 2013, p. 179.

${ }^{14}$ PEREIRA, Caio Mário da Silva. Instituições de Direito Civil, v. III, Contratos. 19. ed. Rio de Janeiro: Forense, 2015, p. 185.

${ }^{15}$ LGOW, Carla Wainer Charléo. Direito de Preferência. p. 24.

${ }^{16}$ Já que o artigo $8^{\circ}$ da Lei no $8.245 / 91$ prevê que "se o imóvel for alienado durante a locação, o adquirente poderá denunciar o contrato, com o prazo de noventa dias para a desocupação, salvo se a locação for por tempo determinado e o contrato contiver cláusula de vigência em caso de alienação e estiver averbado junto à matrícula do imóvel".
} 
em proprietário do imóvel". Diante disso, seria "justificada [a] restrição ao direito de o proprietário dispor da coisa". ${ }^{17}$

Veja-se que o interesse da lei em instituir tal direito se desdobra em uma série de objetivos que estão relacionados com:

a extinção de situações que não promovem devidamente a boa exploração económica dos bens, quer proporcionando o acesso à propriedade a quem já frui os bens ao abrigo de um direito de gozo prolongado no tempo; a eliminação de situações jurídicas potencialmente geradoras de conflitos entre locador e locatário, contribuindo-se assim para a criação de um ambiente de paz social; o prolongamento, no plano ordinário, do direito constitucional de facilitar o acesso à propriedade sobre o locado, a qual ainda corresponde a uma das facetas do direito fundamental à propriedade privada [...]; o reconhecimento do aumento de valor que a atividade do arrendatário não habitacional pode ter dado ao locado. ${ }^{18}$

Com efeito, cabe destacar que tal preocupação é aferível da própria redação da lei. V.g., o artigo 30 da Lei n ${ }^{o} 8.245 / 1991^{19}$ prevê que, no caso de o imóvel estar sublocado na sua totalidade, a preferência caberá ao sublocatário e, em seguida, ao locatário. Ou seja, "protege a lei, primeiramente, quem efetivamente está ocupando o prédio", ${ }^{20}$ aquele que possui os laços mais estreitos com este.

Seguindo essa linha, o parágrafo único do mesmo artigo também corrobora a constatação, já que dispõe que "havendo pluralidade de pretendentes, caberá a preferência ao locatário mais antigo", que é aquele que possui os laços mais duradouros com o imóvel.

Diante do claro intuito da lei em manter os vínculos do locatário com o imóvel, se mostra evidente o caráter personalíssimo da preferência em

\footnotetext{
${ }^{17}$ SOUZA, Sylvio Capanema de. Parecer jurídico elaborado por solicitação da consulente BHG S/A - Brazil Hospitality Group, p. 15-16.

${ }^{18}$ GEMAS, Laurinda; PEDROSO, Albertina; JORGE, João Caldeira. Arrendamento urbano: novo regime anotado e legislação complementar. 3. ed. rev., atual e ampl. Lisboa: Quid Juris, 2009, p. 433.

19 “Art. 30. Estando o imóvel sublocado em sua totalidade, caberá a preferência ao sublocatário e, em seguida, ao locatário. Se forem vários os sublocatários, a preferência caberá a todos, em comum, ou a qualquer deles, se um só for o interessado.

Parágrafo único. Havendo pluralidade de pretendentes, caberá a preferência ao locatário mais antigo, e, se da mesma data, ao mais idoso".

${ }^{20}$ VENOSA, Sílvio de Salvo. Lei do inquilinato comentada. p. 148.
} 
questão, ${ }^{21}$ que encontra previsão legal no artigo 520 do Código Civil, ${ }^{22}$ não

podendo ser cedido, já que "considerando os objectivos prosseguidos pela consagração da preferência em análise, deve entender-se que este direito tem de ser exercido, apenas e só, pelo arrendatário", de modo que um “entendimento contrário conduzirá à inviabilização dos fins em causa". ${ }^{23}$

Por fim, deve-se destacar que outra consequência dessa intenção legal é a de que será nula a cláusula do contrato de locação que, de forma antecipada, implique na renúncia ao direito de preferência, ${ }^{24}$ por força do artigo 45 da Lei $\mathrm{n}^{\mathrm{o}} 8.245 / 91,{ }^{25}$ que dispõe que são nulas de pleno direito as cláusulas que visem a elidir os objetivos daquela lei.

\subsection{Pressupostos para o exercício do direito}

De acordo com a primeira parte do caput do artigo 27 da Lei de Locações, ${ }^{26}$ "no caso de venda, promessa de venda, cessão ou promessa de

21 "A prelação é direito personalíssimo, inerente à pessoa do respectivo titular." (MONTEIRO, Washington; MALUF, Carlos; DA SILVA, Regina. Curso de Direito Civil 5 - Direito das Obrigações $2^{a}$ Parte. 41. ed. São Paulo: Saraiva, 2014, p. 155); "O pactum protimiseos há de reunir alguns requisitos que juridicamente o caracterizam: $a$ ) é personalíssimo, no sentido de que somente pode exercê-lo o próprio vendedor, que não o transmite nem por ato inter vivos nem causa mortis (Código Civil, art. 520)" (PEREIRA, Caio Mário da Silva. Instituições de Direito Civil, v. III. p. 187); "O direito de preferência é considerado personalíssimo, extinguindo-se no prazo estipulado, ou no prazo decadencial em que não for exercido, uma vez deflagrado o fato-tipo que o torna concreto, ou ainda pela morte do vendedor, o que ocorrer primeiro. Assim, falecendo o vendedor, não passará aos seus herdeiros; bem assim, em vida, não poderá de nenhuma forma ser transmitido" (TEPEDINO, Gustavo, BARBOZA, Heloisa Helena; MORAES, Maria Celina Bodin de (Coord.). Código Civil interpretado conforme a Constituição da República. v. 2. 2. ed. rev. e ampl. Rio de Janeiro: Renovar, 2012, p. 189).

22 "Art. 520. O direito de preferência não se pode ceder nem passa aos herdeiros".

${ }^{23}$ GEMAS, Laurinda; PEDROSO, Albertina; JORGE, João Caldeira. Arrendamento urbano. p. 433.

${ }^{24}$ SOUZA, Sylvio Capanema de. A Lei do Inquilinato comentada: artigo por artigo. 11. ed. Rio de Janeiro: Forense, 2019, p. 164.

25 “Art. 45. São nulas de pleno direito as cláusulas do contrato de locação que visem a elidir os objetivos da presente lei, notadamente as que proíbam a prorrogação prevista no art. 47, ou que afastem o direito à renovação, na hipótese do art. 51, ou que imponham obrigações pecuniárias para tanto".

26 "Art. 27. No caso de venda, promessa de venda, cessão ou promessa de cessão de direitos ou dação em pagamento, o locatário tem preferência para adquirir o imóvel locado, em igualdade de condições com terceiros, devendo o locador dar-lhe conhecimento do negócio mediante notificação judicial, extrajudicial ou outro meio de ciência inequívoca".

Parágrafo único. A comunicação deverá conter todas as condições do negócio e, em especial, o preço, a forma de pagamento, a existência de ônus reais, bem como o local e horário em que pode ser examinada a documentação pertinente. 
cessão de direitos ou dação em pagamento, o locatário tem preferência para adquirir o imóvel locado, em igualdade de condições com terceiros".

Assim, de início, cabe pontuar que o mais basilar pressuposto para que o direito de preferência do locatário possa ser por ele exercido é a decisão livre do sujeito passivo da relação prelatícia em alienar o imóvel alugado. Além disso, também há que se destacar que é necessário um projeto efetivo de contrato, tendo o sujeito passivo decidido alienar em condições determinadas, bem como um terceiro interessado no negócio, com o qual tenha sido ajustado esse projeto de contrato. ${ }^{27}$

Vale ressaltar, inclusive, que a existência de um terceiro interessado é um ponto fundamental, já que mesmo que o sujeito passivo decida alienar o imóvel e tenha decidido as condições em que pretende fazê-lo, qualquer comunicação feita ao preferente nesse sentido poderá ser considerada, no máximo, uma proposta de alienação - o que poderá levar a uma contratação com base em proposta e aceitação, mas não a um exercício do direito de preferência. $^{28}$

Inclusive, ANTÓNIO MENEZES CORDEIRo entende que o direito de preferência apenas "mostra as suas potencialidades quando o obrigado à preferência obtenha uma proposta (ou aquiescência) firme, por parte de um terceiro", e é apenas assim que será possível entrar no âmbito do procedimento que poderá levar ao exercício da preferência. ${ }^{29}$

Esse terceiro também se faz relevante porque a lei prevê expressamente que a preferência do locatário pressupõe igualdade de

\footnotetext{
${ }^{27}$ LGOW, Carla Wainer Charléo. Direito de Preferência. p. 64.

${ }^{28}$ Nesse sentido está a lição de Agostinho Cardoso Guedes: "Se o sujeito passivo simplesmente decidiu contratar, e ainda que tenha definido em que condições o pretende fazer, qualquer aviso que ele faça ao preferente a esse respeito terá um teor meramente informativo dessa decisão, ou, quando muito, será uma simples proposta de alienação do bem considerado dirigida ao preferente; ora, nenhuma destas duas situações visa oferecer prioridade ao preferente, pelo menos uma prioridade concreta, que é a única que pode ser objecto de protecção pelo instituto da preferência" (GUEDES, Agostinho Cardoso. O Exercício do Direito de Preferência. p. 358). No mesmo sentido: "a comunicação ao preferente de um contrato perspectivado, sem que haja qualquer terceiro interessado na realização de tal negócio, poderá (eventualmente) resultar numa vulgar contratação, mas não decerto no exercício de um direito de preferência". (BARATA, Carlos Lacerda. Da obrigação de preferência: contributo para o estudo do artigo $416^{\circ}$ do Código Civil. Coimbra: Coimbra Editora, 2002, p. 27).

${ }^{29}$ CORDEIRO, António Menezes. Tratado de Direito Civil Português, v. II, tomo II. p. 493.
} 
condições com terceiros, tanto quanto ao preço, à forma de pagamento e às garantias. ${ }^{30}$

Ademais, é importante mencionar que a preferência em análise apenas terá lugar nos casos de alienação onerosa do imóvel, ${ }^{31}$ nas hipóteses previstas no artigo 27 da Lei de Locações, sendo elas: venda, promessa de venda, cessão ou promessa de cessão de direitos e dação em pagamento.

Nessa linha, a Lei no 8.245/1991 também prevê de forma expressa, em seu artigo $32,{ }^{32}$ alguns casos que estão fora do alcance do direito de preferência, quais sejam: perda da propriedade ou venda por decisão judicial, permuta, doação, integralização de capital, cisão, fusão e incorporação.

No entanto, é necessário salientar que se for comprovada simulação nesses negócios, especialmente nos casos de permuta ${ }^{33}$ e doação, em ação anulatória do negócio jurídico ou de forma incidental em processo no qual se discute o direito de preferência, deve ser garantido ao locatário o exercício desse direito. $^{34}$

Em acréscimo aos casos previstos no caput do artigo 28 foram previstas outras hipóteses pela Lei $\mathrm{n}^{\circ}$ 10.931/2004, que incluiu um parágrafo único no artigo. São elas a constituição da propriedade fiduciária e de perda

\footnotetext{
${ }^{30}$ SOUZA, Sylvio Capanema de. A Lei do Inquilinato comentada. p. 163.

${ }^{31}$ SIMÃO, José Fernando. Legislação civil especial: locação e propriedade fiduciária. São Paulo: Atlas, 2007, p. 53.

32 “Art. 32. O direito de preferência não alcança os casos de perda da propriedade ou venda por decisão judicial, permuta, doação, integralização de capital, cisão, fusão e incorporação.

Parágrafo único. Nos contratos firmados a partir de $1^{\circ}$ de outubro de 2001, o direito de preferência de que trata este artigo não alcançará também os casos de constituição da propriedade fiduciária e de perda da propriedade ou venda por quaisquer formas de realização de garantia, inclusive mediante leilão extrajudicial, devendo essa condição constar expressamente em cláusula contratual específica, destacando-se das demais por sua apresentação gráfica".

${ }^{33}$ Com relação à permuta, Carla Wainer Charléo Lgow cita um caso (TJRJ, Ap. Cív. no 6274618.2008.8.19.0001, $4^{\text {a }}$ C.C., Rel. Des Sifney Hartung, Rio de Janeiro, j. em 22.10.2009) em que o Tribunal de Justiça do Estado do Rio de Janeiro entendeu que um contrato de permuta deveria, na verdade, ser considerado um contrato de compra e venda, vaja-se: "nesse sentido já se manifestou o Tribunal de Justiça do Rio de Janeiro, em precedente que versava sobre o direito de preferência do locatário de imóvel comercial. Como a Lei de Locações é clara ao estabelecer, no caput de seu artigo 32, que a preferência não abrange o negócio jurídico de permuta, sujeito passivo e terceira, para afastar o direito do locatário, celebraram um contrato misto, que deveria ser adimplido pelo terceiro parte em dinheiro, parte em bens. A despeito da forma com que o negócio foi estruturado, decidiu o tribunal que, por ser quantitativamente irrelevante, no momento global, aparte devida pelo terceiro adquirente em bens, o negócio deveria ser considerado uma compra e venda, para efeito de incidência do direito de preferência" (LGOW, Carla Wainer Charléo. Direito de Preferência. p. 34).

${ }^{34}$ VENOSA, Sílvio de Salvo. Lei do inquilinato comentada. p. 150.
} 
da propriedade ou venda por quaisquer formas de realização de garantia, inclusive mediante leilão extrajudicial.

Dessa forma, verificados os pressupostos mencionados acima passase, portanto, para a fase do procedimento que pode levar ao exercício do direito de preferência pelo locatário.

\subsection{O procedimento para o exercício do direito}

A segunda parte do caput do artigo 27 da Lei de Locações prevê que o locador deverá dar ao locatário conhecimento do negócio preferível a que visa celebrar "mediante notificação judicial, extrajudicial ou outro meio de ciência inequívoca" para que este possa decidir se exercerá a preferência que a lei lhe garante. Essa é, portanto, a comunicação para preferência.

Como se pode observar pela leitura do disposto no artigo, o legislador não estabeleceu um meio específico para que seja feita a comunicação, exigindo apenas que a sua ciência seja inequívoca. Assim, entende-se que é válido qualquer meio devidamente comprovado de comunicação, desde que esta seja feito por escrito. ${ }^{35}$

No entanto, quanto ao escopo dessa comunicação, o parágrafo único do artigo 27, estabelece requisitos específicos sem os quais esta será reputada ineficaz, ${ }^{36}$ determinando que deve a comunicação conter todas condições do negócio, "em especial, o preço, a forma de pagamento, a existência de ônus reais, bem como o local e horário em que pode ser examinada a documentação pertinente".

\footnotetext{
${ }^{35}$ SIMÃO, José Fernando. Legislação civil especial. p. 54. O autor diz ainda que "a comunicação geralmente é feita por carta com aviso de recebimento, ou mesmo por uma notificação extrajudicial. Nada impede que o locador, pessoalmente, entregue correspondência ao inquilino informando as condições comples do negócio, ou envie um e-mail informando-o".

${ }^{36}$ Nesse sentido: "Está bem disciplinado na lei o exercício do direito de preferência, desde o aviso que o proprietário-locador deve fazer a respeito até o conteúdo dessa comunicação, a qual, para ser tida por eficaz, deve conter todos os requisitos mencionados" (SANTOS, Gildo dos. Locação e despejo. p. 208); "Qualquer meio de comunicação que não permita o perfeito conhecimento das condições da venda do imóvel ao locatário será ineficaz" (BUFULIN, Augusto Passamani. Breves notas sobre o direito de preferência na locação de imóveis urbanos. p. 107); "Daí se conclui que deverá ser tido como ineficaz comunicação que omita essas formalidades" (VENOSA, Sílvio de Salvo. Lei do inquilinato comentada. p. 145).
} 
Tais condições são tidas como elementos essenciais da comunicação, já que o locatário precisa ter à sua disposição todos os elementos que se mostrem relevantes e necessários para a formação da sua vontade de exercer ou não a preferência. ${ }^{37}$

Uma vez feita a comunicação da forma devida, o locatário, segundo dispõe o artigo 28 da Lei $n^{\circ} 8.245 / 1991,{ }^{38}$ se quiser exercer a preferência, deverá manifestar, de maneira inequívoca, a sua aceitação integral à proposta, no prazo de trinta dias, sob pena de caducar o seu direito. O prazo será iniciado na data do efetivo recebimento da comunicação e, como é de decadência, não se interrompe e nem se suspende. ${ }^{39}$

Quanto ao ponto, é importante destacar que existe uma divergência quanto à qualificação da comunicação para preferência como proposta contratual. Segundo a corrente que entende dessa forma, por meio da comunicação, o vinculado à preferência estaria a cumprir o seu dever principal, que seria o de concluir o contrato projetado com o preferente, caso este assim deseje. ${ }^{40}$

Isso porque, tal como ensina CAIO MÁRIO DA SILVA PEREIRA, uma vez feita a proposta, a ela está o proponente vinculado e, com a respectiva aceitação por parte do oblato, a oferta se transforma em um contrato. ${ }^{41}$ Dessa forma, com a aceitação do locatário/preferente, restaria celebrado o contrato de compra e venda do imóvel a ele locado.

No entanto, CARla WAINER Charléo LgOW diverge desse entendimento e critica a redação dos artigos 28 e $29^{42}$ da Lei n ${ }^{\circ}$ 8.245/1991, destacando que os dois dispositivos, de modo, ao que tudo indica, atécnico, identificam a comunicação para a preferência como uma proposta contratual.

\footnotetext{
${ }^{37}$ COSTA, Mário Júlio de Almeida. Direito das Obrigações. 8. ed. rev. e aum. Coimbra: Almedina, 2001, p. 400.

38 “Art. 28. O direito de preferência do locatário caducará se não manifestada, de maneira inequívoca, sua aceitação integral à proposta, no prazo de trinta dias".

${ }^{39}$ VENOSA, Sílvio de Salvo. Lei do inquilinato comentada. p. 147.

${ }^{40}$ LGOW, Carla Wainer Charléo. Direito de Preferência. p. 79.

${ }^{41}$ PEREIRA, Caio Mário da Silva. Instituições de Direito Civil, v. III. p. 37 e 40.

42 “Art. 29. Ocorrendo aceitação da proposta, pelo locatário, a posterior desistência do negócio pelo locador acarreta, a este, responsabilidade pelos prejuízos ocasionados, inclusive lucros cessantes".
} 
A autora aponta que o artigo 27 da mesma lei, ao instituir a obrigação de comunicar, é expresso ao prever que o locador dever dar ao locatário "conhecimento do negócio mediante notificação judicial, extrajudicial ou outro meio de ciência inequívoca", o que é algo bastante diverso de uma exigência em que o locador submeta uma proposta ao locatário. Assim, uma leitura sistemática parece apta a afastar a interpretação literal dos artigos 28 e $29 .{ }^{43}$

Dessa forma, segundo o entendimento de CARLA WAINER CHARLÉo LGOW, caso o locatário aceite os termos da comunicação feita pelo locador, tal ato constituirá a declaração de preferência. A principal consequência dessa declaração positiva do locatário/preferente, que traduz o exercício do seu direito, "é a constituição, na esfera jurídica do vinculado à preferência, de uma nova obrigação, de contratar com o preferente nos mesmos termos e condições do projeto de contrato ajustado com o terceiro". ${ }^{44}$

No entanto, cabe frisar que se o locatário responder à comunicação suscitando que aceita os termos da comunicação mediante determinadas condições ou se, até mesmo, propor novos termos para a realização do negócio ao locador, tais atos não serão reputados como exercício do direito de preferência. ${ }^{45}$

Nesse sentido, AgOstinho CARDOSO Guedes destaca que "qualquer tentativa por parte do preferente em melhorar o conteúdo do contrato ou ganhar tempo, com tentativas de negociação ou respostas equívocas, poderá conduzir à caducidade do seu direito, pura e simplesmente". ${ }^{46}$

Já se o locatário deixar transcorrer in albis o prazo de trinta dias, quedando-se inerte, o seu direito de prelação será extinto, visto que a sua

\footnotetext{
${ }^{43}$ LGOW, Carla Wainer Charléo. Direito de Preferência. p. 80.

${ }^{44}$ LGOW, Carla Wainer Charléo. Direito de Preferência. p. 96.

${ }^{45}$ BUFULIN, Augusto Passamani. Breves notas sobre o direito de preferência na locação de imóveis urbanos. p. 108.

${ }^{46}$ GUEDES, Agostinho Cardoso. O Exercício do Direito de Preferência. p. 520.
} 
inércia corresponderá à manifestação de vontade em sentido negativo, isto é, de não ter pretensão de exercê-lo. ${ }^{47}$

Por outro lado, caso não haja a observância do procedimento estabelecido pela lei e havendo o descumprimento dos deveres impostos ao locador, ou, até mesmo, a depender da maneira que o locatário exerça o seu direito, a relação de preferência pode vir a entrar em uma fase patológica, em desacordo com a forma ideal em que deveria se dar. É o que se passa a demonstrar a seguir.

\subsection{A fase patológica da relação de preferência}

A fase patológica que pode acometer a relação prelatícia no âmbito das locações urbanas se dá, de maneira mais usual, pelo descumprimento dos deveres específicos previstos pela Lei de Locações, em especial pelo descumprimento do dever de comunicação imposto ao locador para que o locatário possa exercer ou não o seu direito, o que vem a acarretar na alienação do imóvel ao terceiro, sendo o locatário preterido no seu direito de prelação.

Nessa situação, há meios à disposição do locatário para que ele possa fazer valer o seu direito ou, ao menos, remediar os danos que veio a sofrer. Assim, há dois meios essenciais dos quais o locatário poderá se socorrer: poderá ajuizar uma ação de perdas e danos, com fulcro em direito pessoal, ou, poderá entrar com uma ação de adjudicação, já que o seu direito poderá ter eficácia real. ${ }^{48}$

Nesse sentido, segundo dispõe caput do artigo 33 da Lei de Locações:

O locatário preterido no seu direito de preferência poderá reclamar do alienante as perdas e danos ou, depositando o preço e demais despesas do ato de transferência, haver para si o imóvel locado, se o requerer no prazo de seis meses, a contar do

\footnotetext{
${ }^{47}$ TUCCI, Rogério de Lauria; AZEVEDO, Álvaro Villaça. Tratado da locação predial urbana. v.1. São Paulo: Saraiva, 1980, p. 268.

${ }^{48}$ BUFULIN, Augusto Passamani. Breves notas sobre o direito de preferência na locação de imóveis urbanos. p. 113.
} 
registro do ato no cartório de imóveis, desde que o contrato de locação esteja averbado pelo menos trinta dias antes da alienação junto à matrícula do imóvel.

Pela leitura do dispositivo, vê-se que um ponto de suma importância para definir os meios à disposição do locatário para tutelar o seu direito é se o contrato de locação está ou não averbado junto à matrícula do imóvel. Isso porque, caso essa averbação tenha sido feita pelo menos trinta dias ${ }^{49}$ antes da alienação do imóvel, ${ }^{50}$ o seu direito de preferência passa a ser dotado de eficácia real.

Como assevera Sílvio DE SALVo VENOSA, “certas relações oriundas de contratos, por força de disposição legal, alcançam uma altitude de direito real", sendo exatamente o que ocorre nessa hipótese, na qual "o contrato de locação, com o registro imobiliário, permite que o locatário oponha o seu direito de preferência erga omnes, isto é, perante qualquer um que venha a adquirir a coisa locada".51

Assim, "verifica-se que o contrato de locação, embora não tenha poder de dar nascimento a direito real, pode interferir diretamente na disponibilidade do imóvel". 52

No entanto, para que o locatário possa fazer valer o seu direito com eficácia real, se utilizando da ação de adjudicação compulsória do imóvel, é necessário que ele a ajuíze no prazo decadencial ${ }^{53}$ de seis meses, estabelecido

\footnotetext{
49 “E por que a averbação do contrato deve ocorrer no mínimo 30 dias antes da alienação? Porque o prazo de validade das matrículas expedidas pelos Cartórios de Registro de Imóveis é de 30 dias. Assim, o adquirente do imóvel que obteve uma matrícula atualizada do imóvel a ser comprado certamente saberá da existência da locação" (SIMÃO, José Fernando. Legislação civil especial. p. $60)$.

${ }^{50} \mathrm{O}$ parágrafo único do mesmo artigo 33 ainda prevê que "a averbação far-se-á à vista de qualquer das vias do contrato de locação desde que subscrito também por duas testemunhas".

${ }^{51}$ VENOSA, Sílvio de Salvo. Lei do inquilinato comentada. p. 153. Quanto ao ponto, destaca Ronald Schulman que "na alienação do prédio locado não está em jogo apenas o direito de preferência do locatário, mas também o do adquirente de boa-fé, que não teria como se precatar, na generalidade dos casos, se a lei não impusesse a obrigação de registro" (SCHULMAN, Ronald. Considerações sobre o direito de preferência na locação urbana. Revista dos Tribunais, São Paulo, v. 73, n. 588, p. 261-265, out. 1984, p. 264).

${ }^{52}$ TWORKOWSKI, Carlos Alberto. A averbação e o registro dos contratos de locação no registro de imóveis: repercussões legais. Revista de Direito Imobiliário. Instituto de Registro Imobiliário do Brasil /Cont. de/RIRI, São Paulo, v. 30, n. 62, p. 15-26., jan. 2007, p. 25.

53 “o prazo de seis meses é decadencial e deve ser contado efetivamente a partir do registro e não do contrato de compra e venda propriamente dito" (BUFULIN, Augusto Passamani. Breves notas sobre o direito de preferência na locação de imóveis urbanos. p. 113).
} 
pelo já mencionado artigo 33, contados a partir do registro da alienação do imóvel no Cartório de Imóveis. Com efeito, como tal prazo tem natureza decadencial, de modo que não se interrompe ou se suspende, ao seu término o direito é extinto. ${ }^{54}$

Além disso, ao ajuizar a referida ação, o locatário deverá realizar o depósito do valor pelo qual o imóvel foi vendido ao terceiro, acrescido das despesas realizadas com a sua transferência - ou seja, com a escritura, registro, pagamento do imposto de transmissão da propriedade imobiliária, entre outras. ${ }^{55}$ Vale destacar, ainda, que o locatário deverá promover a ação adjudicatória em face tanto do alienante quanto do terceiro adquirente, e o título a ser formado pela sentença corresponderá ao título da alienação infringente. ${ }^{56}$

Ademais, também é importante salientar que a Lei de Locações não confere o direito de postular a nulidade da alienação ao locatário preterido em seu direito de prelação, já que ela resolve a questão apenas no plano da eficácia do contrato, não se tratando de hipótese de invalidade da alienação. Isso porque, caso a lei tivesse optado pela invalidade, a consequência do pedido de anulação significaria o retorno do bem à propriedade do locador (retorno ao status quo ante), o que não cumpriria o objetivo do direito, já que o locatário permaneceria na condição de locatário, e não na de proprietário do imóvel. ${ }^{57}$

Com efeito, PONTES DE MiRANDA, ao tratar do artigo $9^{\circ}$ da Lei $n^{\circ}$ $3.912 / 1961,{ }^{58}$ antes de haver a previsão de que a eficácia real ao direito de preferência do locatário somente se daria com a averbação do contrato no

\footnotetext{
${ }^{54}$ SIMÃO, José Fernando. Legislação civil especial. p. 61.

${ }^{55}$ SANTOS, Gildo dos. Locação e despejo. p. 222.

56 VENOSA, Sílvio de Salvo. Lei do inquilinato comentada. p. 154.

57 SIMÃO, José Fernando. Legislação civil especial. p. 62. No mesmo sentido: "o sucesso da adjudicação não implica a nulidade da compra e venda, posto que o bem não retorna ao vendedor. Há, no caso, apenas consequência no plano da eficácia do negócio jurídico, sendo a compra e venda tida como ineficaz com relação ao locatário" (BUFULIN, Augusto Passamani. Breves notas sobre o direito de preferência na locação de imóveis urbanos. p. 114)

58 “Art. $9^{\circ}$ - Em caso de alienação do imóvel locado, o inquilino, em igualdade de condições, preço e garantias, terá sempre a preferência para a sua aquisição, a ser manifestada dentro de 30 (trinta) dias, a partir da data em que o locador lhe comunicar, por escrito, a intenção e a forma de vendê-lo."
} 
Registro Imobiliário, possuía o entendimento de que tal direito teria o condão

de tornar ineficaz, com relação ao seu titular, qualquer alienação ou promessa de alienação que tenha ocorrido sem a pertinente comunicação para que este pudesse exercer o seu direito. Veja-se:

Uma das consequiências das regras jurídicas, que estabelecem, ex lege, o direito de preferência, é a de fazer ineficaz, em relação ao titular do direito de preferência, qualquer alienação, que se tenha operado, ou qualquer promessa de alienação, que se haja concluído sem ter havido a prévia comunicação ao titular do direito de preferência, para que, dentro do prazo, exercesse o seu direito. A comunicação e o transcurso do prazo, antes do negócio jurídico, são pressupostos necessários para a eficácia. Se a pessoa que teria de comunicar o negócio jurídico futuro não o fez, ou o fez porém não aguardou que transcorresse o prazo, o direito de preferência está incólume. A ineficácia relativa permite que o titular do direito de preferência o exerça com o depósito da quantia. ${ }^{59}$

No entanto, como visto, de acordo com a legislação em vigor, se o contrato de locação não estiver devidamente averbado, a locação só gera efeitos obrigacionais. ${ }^{60}$ Assim, caso seja preterido no seu direito de prelação,

\footnotetext{
${ }^{59}$ MIRANDA, Pontes de. Tratado de Direito Privado. t. XL. 2. ed. Rio de Janeiro: Borsoi, 1962, p. 268-269.

60 "Sem a averbação do contrato no Registro de Imóveis, a locação só gera efeitos obrigacionais. Com a averbação, o contrato de locação se torna conhecido de terceiros, em razão da publicidade e, portanto, o adquirente do imóvel tem conhecimento da existência do inquilino, ao consultar a matrícula da coisa a ser vendida. Não pode alegar eventual boa-fé do terceiro, pois da análise da matrícula surge a ciência da existência de um inquilino que, por lei, tem o direito de preferência" (SIMÃO, José Fernando. Legislação civil especial. p. 59). Veja-se, nesse sentido, esclarecedor julgado do Superior Tribunal de Justiça: "PROCESSUAL CIVIL. NEGATIVA DE PRESTAÇÃO JURISDICIONAL. NÃO OCORRÊNCIA. CIVIL. LOCAÇÃO. DIREITO DE PREFERÊNCIA. EFEITOS OBRIGACIONAL E REAL. PLEITO INDENIZATÓRIO E DE ADJUDICAÇÃO COMPULSÓRIA DO IMÓVEL. CONTRATO DE LOCAÇÃO NÃO AVERBADO NO CARTÓRIO DE REGISTRO DE IMÓVEIS POR FALHA DO LOCADOR. IRRELEVÂNCIA. INEXISTÊNCIA DE DIREITO DE REAVER O BEM. MANUTENÇÃO DO ARESTO RECORRIDO. 1. Afasta-se a alegada negativa de prestação jurisdicional quando o acórdão recorrido, integrado por julgado proferido em embargos de declaração, dirime, de forma expressa, congruente e motivada, as questões suscitadas nas razões recursais. 2. O art. 27 da Lei n. 8.245/91 prevê os requisitos para que o direito de preferência seja exercido pelo inquilino que tenha interesse em adquirir o imóvel locado em igualdade de condições com terceiros, sendo certo que, em caso de inobservância de tal regramento pelo locador, poderá o locatário fazer jus a indenização caso comprove que tinha condições de comprar o bem nas mesmas condições que o adquirente. 3 . Além dos efeitos de natureza obrigacional correspondentes ao direito a perdas e danos, o desrespeito à preempção do locatário pode ter eficácia real consubstanciada no direito de adjudicação compulsória do bem, uma vez observados os ditames do art. 33 da Lei do Inquilinato. 4. O direito real à adjudicação do bem somente será exercitável se o locatário a) efetuar o depósito do preço do bem e das demais despesas de transferência de propriedade do imóvel; b) formular referido pleito no prazo de 6 (seis) meses do registro do contrato de compra e venda do imóvel locado adquirido por terceiros; b) promover a averbação do contrato de locação assinado por duas testemunhas na matrícula do bem no cartório de registro de imóveis, pelo menos 30 (trinta) dias antes de referida alienação. 5. Impõese a obrigação legal de averbar o contrato de locação para possibilitar a geração de efeito erga omnes no tocante à intenção do locatário de fazer valer seu direito de preferência e tutelar os interesse de
} 
ao locatário caberá tão somente ajuizar a ação indenizatória para "exercer o direito pessoal consistente no pedido de perdas e danos que eventualmente venha a sofrer pela não observância do direito de preferência". ${ }^{61}$

Nessa ação, o locatário somente terá êxito se demonstrar o efetivo prejuízo suportado por ter sido preterido na alienação do imóvel, bem como comprovar que tinha condições de adquiri-lo, nas mesmas condições que o fez o terceiro adquirente. ${ }^{62}$

Cabe mencionar, ainda, que a ação indenizatória em questão não se submete ao prazo decadencial de seis meses, mas sim ao prazo prescricional para a pretensão decorrente da responsabilidade civil contratual, de dez anos contados da data da alienação, ${ }^{63}$ além de dever ser movido unicamente contra

terceiros na aquisição do bem imóvel. 6. Ainda que obstada a averbação do contrato de locação por falha imputável ao locador, não estaria assegurado o direito à adjudicação compulsória do bem se o terceiro adquirente de boa-fé não foi cientificado da existência de referida avença quando da lavratura da escritura de compra e venda do imóvel no cartório de registro de imóveis. 7. Recurso especial conhecido e desprovido" (STJ, REsp n ${ }^{\circ}$ 1.554.437/SP, $3^{\text {a }}$ Turma, Rel. Ministro João Otávio De Noronha, Brasília, j. em 02.06.2016).

${ }^{61}$ BUFULIN, Augusto Passamani. Breves notas sobre o direito de preferência na locação de imóveis urbanos. p. 114

${ }^{62}$ SANTOS, Gildo dos. Locação e despejo. p. 221. Veja-se, ainda, alguns julgados em que o tema foi debatido: "AGRAVO INTERNO DA DECISÃO MONOCRÁTICA. LOCATÁRIO INADIMPLENTE HÁ 13 ANOS. DEMONSTRADO QUE NÃO DISPÕE DE PATRIMÔNIO PARA AQUISIÇÃO DO IMÓVEL. NÃO CONFIGURADAS AS PERDAS E DANOS, NOTADAMENTE MORAIS, PELA NÃO OBSERVÂNCIA DO DIREITO DE PREFERÊNCIA. DESPROVIMENTO DO RECURSO.” (TJRJ, Ap. Cív. nº 0123222- 27.2005.8.19.0001, Rel. Des. Helena Candida Lisboa Gaede, 3 ${ }^{\text {a }}$ C.C., j. em 16.06.2010); "APELAÇÕES - AÇÃO INDENIZATÓRIA - LOCAÇÃO - Autora preterida em seu direito de preferência sobre a aquisição do imóvel que locava - Pleito de perdas e danos que prescinde da averbação do contrato na matrícula do imóvel, necessária apenas para o exercício do direito real de adjudicação - Precedentes do Superior Tribunal de Justiça - Autora que manifestou o seu interesse dentro do prazo legal e comprovou que possuía condições financeiras de adquirir o imóvel na mesma conjuntura em que ele foi alienado a terceiro - DANOS MATERIAIS - Gastos com a mudança que restaram demonstrados pelos recibos colacionados aos autos - DANOS MORAIS - Configuração - Evidente a repercussão negativa dos fatos na esfera íntima da requerente, tendo em vista que habitava o imóvel em discussão há mais de 17 anos, tendo de deixar abruptamente o lar onde possuía sua rotina e costumes e no qual, decerto, criou memórias e relações de afeto [...]" (TJSP, Ap. Cív. n ${ }^{\circ}$ 1000357-

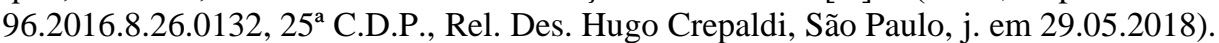

${ }^{63}$ Conforme decisão do Superior de Justiça proferida em 15.05.2019: "CIVIL E PROCESSUAL CIVIL. EMBARGOS DE DIVERGÊNCIA NO RECURSO ESPECIAL. DISSENSO CARACTERIZADO. PRAZO PRESCRICIONAL INCIDENTE SOBRE A PRETENSÃO DECORRENTE DA RESPONSABILIDADE CIVIL CONTRATUAL. INAPLICABILIDADE DO ART. 206, § $3^{\circ}$, V, DO CÓDIGO CIVIL. SUBSUNÇÃO À REGRA GERAL DO ART. 205, DO CÓDIGO CIVIL, SALVO EXISTÊNCIA DE PREVISÃO EXPRESSA DE PRAZO DIFERENCIADO. CASO CONCRETO QUE SE SUJEITA AO DISPOSTO NO ART. 205 DO DIPLOMA CIVIL. EMBARGOS DE DIVERGÊNCIA PROVIDOS. I - Segundo a jurisprudência deste Superior Tribunal de Justiça, os embargos de divergência tem como finalidade precípua a uniformização de teses jurídicas divergentes, o que, in casu, consiste em definir o prazo prescricional incidente sobre os casos de responsabilidade civil contratual. II - A prescrição, enquanto corolário da segurança jurídica, constitui, de certo modo, regra restritiva de direitos, não podendo assim 
o alienante, não possuindo o terceiro adquirente legitimidade para figurar no polo passivo. ${ }^{64}$

De outro giro, deve-se tratar aqui de mais uma hipótese em que a relação de preferência pode não seguir o seu curso ideal por causa de um comportamento do locador, adquirindo um viés patológico: trata-se da hipótese na qual, tendo o locatário recebido do locador a comunicação para exercer o seu direito de prelação e optando por exercê-lo, aceitando a proposta, há a desistência do negócio por parte do locador.

Nesse sentido, conforme prevê o artigo 29 da Lei $\mathrm{n}^{\circ}$ 8.245/1991, "ocorrendo aceitação da proposta, pelo locatário, a posterior desistência do negócio pelo locador acarreta, a este, responsabilidade pelos prejuízos ocasionados, inclusive lucros cessantes". Segundo o disposto no artigo, poderá o locatário ajuizar ação pleiteando a reparação pelos eventuais prejuízos que a desistência do negócio o gerou. Porém, vale salientar que a ele caberá o ônus de provar que houve a aceitação dos termos da comunicação feita pelo locador e o posterior arrependimento deste, além do montante dos prejuízos efetivamente sofridos. ${ }^{65}$

Quanto ao ponto, vale destacar novamente a crítica feita por CARLA WAINER CHARLÉO LGOW (mencionada no item 1.4) de que o legislador teria, de modo atécnico, confundido a comunicação para preferência com uma proposta contratual no artigo $29,{ }^{66}$ já que, a rigor, a proposta vincula o

comportar interpretação ampliativa das balizas fixadas pelo legislador. III - A unidade lógica do Código Civil permite extrair que a expressão "reparação civil" empregada pelo seu art. $206, \S 3^{\circ}, \mathrm{V}$, refere-se unicamente à responsabilidade civil aquiliana, de modo a não atingir o presente caso, fundado na responsabilidade civil contratual. IV - Corrobora com tal conclusão a bipartição existente entre a responsabilidade civil contratual e extracontratual, advinda da distinção ontológica, estrutural e funcional entre ambas, que obsta o tratamento isonômico. $\mathrm{V}$ - O caráter secundário assumido pelas perdas e danos advindas do inadimplemento contratual, impõe seguir a sorte do principal (obrigação anteriormente assumida). Dessa forma, enquanto não prescrita a pretensão central alusiva à execução da obrigação contratual, sujeita ao prazo de 10 anos (caso não exista previsão de prazo diferenciado), não pode estar fulminado pela prescrição o provimento acessório relativo à responsabilidade civil atrelada ao descumprimento do pactuado. VI - Versando o presente caso sobre responsabilidade civil decorrente de possível descumprimento de contrato de compra e venda e prestação de serviço entre empresas, está sujeito à prescrição decenal (art. 205, do Código Civil). Embargos de divergência providos" (STJ, EREsp n ${ }^{\circ}$ 1.281.584/SP, Corte Especial, Rel. Min. Benedito Gonçalves, Brasília, j. em 15.05.2019).

${ }^{64}$ VENOSA, Sílvio de Salvo. Lei do inquilinato comentada. p. 155.

${ }^{65}$ SOUZA, Sylvio Capanema de. A Lei do Inquilinato comentada. 167.

${ }^{66}$ LGOW, Carla Wainer Charléo. Direito de Preferência. p. 79. 
proponente e a sua aceitação configura a celebração de um contrato, ${ }^{67}$ de modo que o locador não poderia simplesmente desistir do negócio, tal como prevê o artigo, já que este já teria sido celebrado.

Por fim, cabe consignar que, além das hipóteses aqui tratadas, nas quais, por parte de um ato do locador, a relação prelatícia assume um caráter patológico, se desvirtuando da sua forma ideal, há outras que podem ser ocasionadas por parte de atos do locatário. São estas as hipóteses em que o locatário pode vir a exercer o direito de preferência que a Lei de Locações lhe garante de uma forma ilegítima, constituindo um abuso desse direito.

No entanto, para que bem se possa entender essas hipóteses e delas tratar, faz-se necessária uma adequada compreensão da teoria do abuso do direito e de suas implicações. Com isso, entra-se agora na segunda parte do presente estudo, quanto à análise dessa teoria, para que, após, possa-se tratar do exercício abusivo do direito de preferência.

\footnotetext{
${ }^{67}$ PEREIRA, Caio Mário da Silva. Instituições de Direito Civil, v. III. p. 37 e 40.
} 


\section{CAPÍTULO 2 - O ABUSO DO DIREITO NA PERSPECTIVA CONTEMPORÂNEA}

\subsection{Origens e definição}

Ao longo do tempo, verificou-se que a repressão ao ato ilícito como violação a um direito capaz de gerar dano a outrem se mostrava insuficiente para a tutela das relações sociais. Assim, o instituto do abuso do direito "surgiu justamente no intuito de reprimir os atos que, embora praticados com estrita observância da lei, violavam o seu espírito". ${ }^{68}$

O surgimento da teoria do abuso do direito se deu no final do século XIX, ${ }^{69}$ como uma reação ao caráter absoluto dos direitos subjetivos em sua compreensão advinda da modernidade, como expressão de poder individual quase ilimitado, sendo, ainda, uma das primeiras respostas à divisão tradicional da teoria das fontes, na qual o juiz era colocado no papel passivo de mero aplicador do direito legislado. ${ }^{70}$

As primeiras aparições da figura do abuso do direito foram na jurisprudência francesa, ${ }^{71}$ em casos de direito de vizinhança, como meio de limitar o direito de propriedade - daí se extraí a conclusão de que a sua

\footnotetext{
${ }^{68}$ TEPEDINO, Gustavo, BARBOZA, Heloisa Helena; MORAES, Maria Celina Bodin de (Coord.). Código Civil interpretado conforme a Constituição da República. v. 1. p. 345.

69 No entanto, Giovanni Ettore Nanni suscita que "apesar de não se conhecer uma teoria que limitasse o exercício abuso do direito, era possível notar no Direito Romano a existência, em fragmentos, de noções embrionárias de tal restrição" (NANNI, Giovanni Ettore. Abuso do direito. In: LOTUFO, Renan; NANNI, Giovanni Ettore (Coord.). Teoria geral do direito civil. São Paulo: Atlas, 2008. p. 739)

${ }^{70}$ MIRAGEM, Bruno Nubens Barbosa. Abuso do direito: ilicitude objetiva e limite ao exercício de prerrogativas jurídicas no Direito Privado. 2. ed. rev., atual. e ampl. São Paulo: Revista dos Tribunais, 2013, p 33.

${ }^{71}$ Quanto ao ponto, vale destacar o notório caso Clément-Bayard: "registra-se, por exemplo, interessante episódio do começo do século XX: em terreno próximo do hangar onde construtor de balões dirigíveis guardava seus aparelhos, o proprietário fez erguer altas e pontiagudas torres de madeira, capazes de danificar os dirigíveis que se alçavam ou aterrissavam - acidente que de fato não tardou a suceder. Demandado, alegou aquele que se limitara a exercer direito inerente à propriedade do solo, a saber, o de realizar neste as construções que lhe aprouvessem; mas em todas as instâncias ficou vencido: consideraram os juízos que, à luz das circunstâncias, era manifesto o propósito de prejudicar, e faltava ao proprietário do terreno qualquer interesse ou utilidade em erigir as torres" (MOREIRA, José Carlos Barbosa. Abuso do direito. Revista Síntese de Direito Civil e Processual Civil, São Paulo, n. 26, p. 125-134, nov./dez. 2003, p. 127).
} 
origem é eminentemente jurisprudencial. ${ }^{72}$ Em um segundo momento, ainda na França, teve início um movimento de construção doutrinária, que culminou, posteriormente, na positivação do instituto em diversos países. ${ }^{73}$

No desenvolvimento da teoria do abuso do direito surgiram algumas correntes doutrinárias sobre o tema. Dentre elas, está a dos negativistas, que, pelos mais diversos motivos, não reconheciam qualquer possibilidade de exercício abusivo do direito. ${ }^{74}$

Já dentre os que admitiam a possibilidade do abuso do direito, formouse uma corrente que ligava o abuso à motivação do agente, que veio a receber o nome de subjetivista. As teorias atreladas a essa corrente aproximavam o abuso do direito com a doutrina dos atos emulativos medievais - aqueles praticados com o exclusivo intuito de causar dano a outrem -, entendendo que este restaria configurado desde que verificada a conjunção de dois elementos: a intenção maléfica de causar um dano coberta com a aparência de direito. ${ }^{75}$

Como se percebe, as teorias subjetivistas identificaram no elemento moral um limite externo, extrajurídico, ao exercício dos direitos. No entanto, caberia às teorias da corrente objetivista trazer para o interior da ordem jurídica os padrões valorativos objetivos necessários para a aferição do abuso. $^{76}$ Neste ponto, EDUARDO NUNES DE SOUZA destaca que a teoria finalista, desenvolvida por LOUIS JOSSERAND, teve um papel fundamental, “ao levar em conta que todos os direitos tinham um espírito, uma função

\footnotetext{
72 SCHREIBER, Anderson. A proibição de comportamento contraditório. p. 72.

73 MAIA, Lívia Barboza. Boa-fé objetiva e abuso do direito nas decisões do Tribunal de Justiça do Rio de Janeiro. In: TERRA, Aline de Miranda Valverde; KONDER, Carlos Nelson; GUEDES, Gisela Sampaio da Cruz. Princípios contratuais aplicados: boa-fé, função social e equilíbrio contratual à luz da jurisprudência. Indaiatuba: Foco, 2019, p. 115.

74 SOUZA, Eduardo Nunes de. Abuso do direito: novas perspectivas entre a ilicitude e o merecimento de tutela. Revista Trimestral de Direito Civil, Rio de Janeiro, v. 50, p. 35-91, abr./jun. 2012 , p. 45

75 CARDOSO, Vladimir Mucury. O abuso do direito na perspectiva civil-constitucional. In: MORAES, Maria Celina Bodin (Coord.). Princípios do direito civil contemporâneo. Rio de Janeiro: Renovar, 2006, p. 68-69.

${ }^{76}$ SOUZA, Eduardo Nunes de. Abuso do direito. p. 45.
} 
social que representava seu 'curso natural' e contra o qual seu exercício não poderia postar-se". ${ }^{77}$

Entretanto, ANDERSON SCHREIBER destaca que, de todas as diversas teorias que se dispõe a explicar a definição de abuso do direito, o que se reconhece, atualmente, como sendo essencial ao instituto "é a contrariedade ao fundamento axiológico-normativo do direito exercido". Dessa forma, "abusa do direito quem o exerce de forma aparentemente regular, mas em contradição com os valores que o ordenamento pretende por meio dele realizar". ${ }^{78}$

Seguindo essa linha, PIETRo PerlingIERI entende que "o abuso é o exercício contrário ou de qualquer modo estranho à função da situação subjetiva" e assevera que "tem-se abuso toda vez que um comportamento, ainda que coincidindo com o conteúdo do direito considerado de um ponto de vista formal, substancialmente constitui um seu desvio", ${ }^{79}$

Já CUNHA DE SÁ pontua que “em certa e determinada situação, experimentalmente concreta", pode-se verificar a "concordância com a estrutura formal de um dado direito subjectivo e, simultaneamente, discordância, desvio, oposição, ao próprio valor jurídico que daquele comportamento faz um direito subjectivo". ${ }^{80}$

Nesse sentido, o abuso do direito teria, sob esta concepção, a finalidade de "conformar a autonomia privada aos valores que o ordenamento pretende, por meio daquela situação subjetiva específica, tutelar". ${ }^{81}$ Veja-se que esse reconhecimento do abuso como um instituto que visa impedir o exercício de direitos quando se verifica a desconformidade deste com certos critérios axiológico-materiais, sem uma definição consensual de quais sejam esses critérios, "acabou dando margem a construções ecléticas da noção de

\footnotetext{
${ }^{77}$ SOUZA, Eduardo Nunes de. Abuso do direito. p. 45.

${ }^{78}$ SCHREIBER, Anderson. A proibição de comportamento contraditório. p. 75.

${ }^{79}$ PERLINGIERI, Pietro. O direito civil na legalidade constitucional. Rio de Janeiro: Renovar, 2008, p. 683-684.

${ }^{80}$ CUNHA DE SÁ, Fernando. Abuso do Direito. Coimbra: Almedina, 2005, p. 456.

${ }^{81}$ SCHREIBER, Anderson. A proibição de comportamento contraditório. p. 76.
} 
abuso do direito, vinculados ora à função econômica e social do direito, ora aos bons costumes, ora à boa-fé objetiva". ${ }^{82}$

\subsection{A objetivação do abuso do direito no Código Civil de 2002 e a sua configuração como categoria autônoma que se aplica à todas as situações jurídicas subjetivas}

No Brasil, o abuso do direito não recebeu do Código Civil de 1916 a acolhida que teve em outros ordenamentos à época de sua promulgação. $\mathrm{O}$ artigo 160, inciso I, do Código revogado apenas previa que não constituíam atos ilícitos os praticados no exercício regular do direito. Assim, a teoria do abuso do direito penetrou no ordenamento jurídico brasileiro de forma quase clandestina e sem receber essa dominação, por meio de interpretação $a$ contrario sensu do referido artigo de que atos praticados no exercício irregular de um direito eram ilícitos. ${ }^{83}$

O Código Civil de 2002, por outro lado, em seu artigo $187,{ }^{84}$ consagrou expressamente a teoria do abuso do direito, inovando em relação ao seu antecessor, muito embora não tenha trazido a sua denominação. ${ }^{85} \mathrm{O}$ referido artigo assim dispõe: "também comete ato ilícito o titular de um direito que, ao exercê-lo, excede manifestamente os limites impostos pelo seu fim econômico ou social, pela boa-fé ou pelos bons costumes".

Como se pode observar, o dispositivo adotou uma espécie de concepção eclética do ato abusivo ${ }^{86}$ e parece acolher e sintetizar as suas

\footnotetext{
${ }^{82}$ SCHREIBER, Anderson. A proibição de comportamento contraditório. p. 76.

${ }^{83}$ CARPENA, Heloísa. O Abuso do direito no código de 2002: Relativização de direitos na ótica civil constitucional. In: TEPEDINO, Gustavo (Org.). O Código Civil na Perspectiva CivilConstitucional. Rio de Janeiro: Renovar, 2013, p. 431-432. À época da vigência do Código Civil de 1916 era exatamente essa a interpretação de Everardo da Cunha Luna: "é intuitivo que, se o ato é praticado no exercício irregular de um direito reconhecido, não é lícito, e, não o sendo, só pode ser ilícito, porque não existe, no campo do direito, zona intermediária e incolor, espécie de limbo jurídico, em que licitude e ilicitude perdem sentido e significação" (LUNA, Everardo da Cunha. Abuso do direito. 2. ed. Rio de Janeiro: Forense, 1988, p. 82-83).

84 “Art. 187. Também comete ato ilícito o titular de um direito que, ao exercê-lo, excede manifestamente os limites impostos pelo seu fím econômico ou social, pela boa-fé ou pelos bons costumes".

${ }^{85}$ CARPENA, Heloísa. O Abuso do direito no código de 2002. p. 438.

${ }^{86}$ SCHREIBER, Anderson. A proibição de comportamento contraditório. p. 77.
} 
diferentes concepções, com clara inspiração no artigo 334 do Código Civil português ${ }^{87}$ e com redação muito semelhante a este, ${ }^{88}$ que prevê que "é ilegítimo o exercício de um direito, quando o titular exceda manifestamente os limites impostos pela boa fé, pelos bons costumes ou pelo fim social ou económico desse direito".

Ademais, GIOVANNI ETTORE NANNI também pontua que, pela análise do artigo, pode-se notar que neste foi consagrada a teoria objetivista, já que:

não é necessária a intenção ou a consciência, por parte do agente, de se excederem com o exercício do direito as raias delimitadas pela boa-fé, pelos bons costumes ou pelo fim social ou econômico desse direito, sendo o bastante que, objetivamente, se ultrapassem tais limites. ${ }^{89}$

Tal entendimento foi consagrado na I Jornada de Direito Civil do Conselho da Justiça Federal, coordenada por RUY ROSADO AGUIAR JÚNIOR, na qual foi aprovado o Enunciado n ${ }^{\circ}$ 37, que tem a seguinte previsão: "art. 187: a responsabilidade civil decorrente do abuso do direito independe de culpa e fundamenta-se somente no critério objetivo-finalístico".

O referido enunciado veio para esclarecer as dúvidas sobre a correta aplicação da norma diante de críticas, como as de HELOÍSA CARPENA, sobre a redação do artigo 187, que associa o abuso do direito com o ato ilícito ao utilizar a expressão "também comete ato ilícito", podendo suscitar uma equivocada associação ao ato ilícito previsto no artigo $186 .^{90}$ Segundo a autora:

a concepção do abuso do direito como espécie do ato ilícito, permita-se insistir, além de obscurecer seus contornos, caminha no sentido da responsabilidade subjetiva, sendo a culpa elemento quase indissociável do conceito de ilicitude.

\footnotetext{
${ }^{87}$ CARPENA, Heloísa. O Abuso do direito no código de 2002. p. 438.

88 “A própria lei acusa uma derivação patente de precedentes estrangeiros. $\mathrm{O}$ art. 187 corresponde quase ipsis verbis ao art. 334 do Código Civil português de 1966. (...) recorda-se que ao tempo da elaboração do Anteprojeto do atual Código Civil brasileiro o Código Civil português de 1966 era, salvo erro, o mais recente código civil existente" (ASCENSÃO, José de Oliveira. A desconstrução do abuso do direito. Revista de Direito do Tribunal de Justiça do Estado do Rio de Janeiro, Rio de Janeiro, n. 66, p. 60-82, jan. 2006, p. 60)

${ }^{89}$ NANNI, Giovanni Ettore. Abuso do direito. p. 751.

90 “Art. 186. Aquele que, por ação ou omissão voluntária, negligência ou imprudência, violar direito e causar dano a outrem, ainda que exclusivamente moral, comete ato ilícito".
} 
Trata-se de concepção absolutamente anacrônica, pois a efetiva aplicação da teoria exige que a aferição de abusividade no exercício de um direito seja objetiva, revelada no simples confronto entre o ato praticado e os valores tutelados pelo ordenamento civil constitucional..$^{91}$

Como assevera EDUARDo NUNES DE SOUZA, tanto o abuso do direito quanto o ato ilícito - compreendido como aquele que, praticado sem direito, causa dano a alguém - violam a ordem jurídica e são, assim, "não lícitos", o que não autoriza a conclusão de que o ato ilícito abarcaria também o abusivo. Apesar de o legislador ter disposto no artigo 187 que quem abusa de seu direito "também comete ato ilícito" e de ter reunido as duas figuras no "Título III - Dos Atos Ilícitos", isso não pode levar a argumentos formalistas que identificam no abuso espécie de ato ilícito, entendendo a melhor doutrina que ilícito e abuso são espécies do gênero "antijuridicidade". ${ }^{92}$

Dessa forma, o artigo 187, que associa o abuso do direito com o ato ilícito, "deve ser interpretado como uma referência a uma ilicitude lato sensu", que indica uma "contrariedade ao direito como um todo, e não como uma identificação entre a etiologia do ato ilícito e a do ato abusivo, que são claramente diversas". 93

Nessa mesma linha, entende NANNI no sentido de que "o abuso do direito (art. 187 CC) é uma espécie de ato ilícito lato sensu, sendo instituto autônomo que não se confunde com o ato ilícito stricto sensu (art. 186 CC)", de modo que "est[á] dissociado dos requisitos deste, especialmente no que concerne à culpa". ${ }^{94}$

Já JOSÉ CARLOS BARbOSA MOREIRA afirma que as figuras estariam equiparadas e, em um primeiro momento, parece divergir do posicionamento de que estas seriam distintas, suscitando que "tem-se de convir em que, no

\footnotetext{
${ }^{91}$ CARPENA, Heloísa. O Abuso do direito no código de 2002. p. 439.

92 SOUZA, Eduardo Nunes de. Abuso do direito. p. 67.

93 TEPEDINO, Gustavo, BARBOZA, Heloisa Helena; MORAES, Maria Celina Bodin de (Coord.). Código Civil interpretado conforme a Constituição da República. v. 1. p. 346.

${ }^{94}$ NANNI, Giovanni Ettore. Abuso do direito. p. 748. No mesmo sentido: “é certo que, na linguagem adotada pelo legislador brasileiro, o próprio ato abusivo configura também um ato ilícito, mas um ato ilícito lato sensu (antijurídico), que dispensa prova de culpa, requisito essencial ao ato ilícito stricto sensu (art. 186)" (SCHREIBER, Anderson. A proibição de comportamento contraditório. $\mathrm{p}$. 112).
} 
atual ordenamento, o ato ilícito passa a constituir gênero, com duas espécies, a do art. 186 (violação de direito alheio) e do art. 187 (abuso de direito próprio)" e que "cada espécie tem seus pressupostos". 95

JUDITH MARTINS-COSTA também parece ir por um caminho semelhante, entendendo que a noção de ilicitude civil estabelecida pela lei abarcaria não apenas o que chama de "ilicitude subjetiva, isto é, o ato (doloso ou culposo, voluntário, negligente ou imprudente; comissivo ou omissivo) que viola direito e causa dano a outrem (art. 186)", mas também "a chamada 'ilicitude objetiva' - porque independe de intenção emulativa'. ${ }^{96}$

No entanto, o posicionamento desses dois últimos autores, a rigor, não diverge substancialmente do entendimento de que o abuso do direito detém uma autonomia com relação ao ato ilícito previsto no artigo 186. Nesse sentido, EDUARDO NUNES DE SOUZA suscita a necessidade de se investigar cada opinião doutrinária, já que a mera divergência terminológica acaba por resultar, em grande medida, em uma falsa controvérsia doutrinária, o que reafirma a autonomia do instituto. Veja-se:

Cumpre, porém, investigar, em cada opinião doutrinária, a que figura se alude com a terminologia adotada: não raro inspirada pela sistematização do Código Civil de 2002, a doutrina tem considerado que as hipóteses dos arts. 186 e 187 são espécies distintas de um gênero maior que denomina "ato ilícito". Nesses casos, por evidente, trata-se rigorosamente da mesma sistemática aqui defendida, substituindo-se apenas o adjetivo "antijurídico" pelo termo "ilícito". A mera divergência terminológica resulta, assim, em falsa controvérsia doutrinária; deu-se preferência à designação "ato ilícito" para a figura do art. 186 apenas por força da tradição, a reafirmar a autonomia do abuso do direito, que se evidencia (...). ${ }^{97}$

Além disso, cabe ainda sublinhar que o fato de o Código Civil ter mencionado exclusivamente o termo "direito" no artigo 187 , não obsta o importante reconhecimento de que todas as situações jurídicas subjetivas são passíveis de abuso. ${ }^{98}$

\footnotetext{
${ }^{95}$ MOREIRA, José Carlos Barbosa. Abuso do direito. p. 130.

${ }^{96}$ MARTINS-COSTA, Judith. A boa-fé no direito privado: critérios para sua aplicação. São Paulo: Marcial Pons, 2015, p. 610.

${ }^{97}$ SOUZA, Eduardo Nunes de. Abuso do direito. p. 68.

${ }^{98}$ SOUZA, Eduardo Nunes de. Abuso do direito. p. 62.
} 
Com efeito, tal como sustenta HELOísA CARPENA, ${ }^{99}$ a figura do abuso do direito, embora originalmente atrelada à ideia do exercício abusivo de um direito subjetivo, é admitida em relação a qualquer situação jurídica subjetiva, já que todas elas serão sempre providas de fundamento axiológico - quer se trate de poderes, faculdades, liberdades ou direitos potestativos, todos, a rigor, constituem vantagens, cuja configuração, em última análise, depende da estrutura qualificativa da norma jurídica.

CUNHA DE SÁ ${ }^{100}$ também adota esse raciocínio, entendendo que tanto direitos subjetivos no sentido próprio, liberdades, faculdades ou poderes constituem vantagens, cuja configuração exata depende, ao fim e ao cabo, da estrutura qualificativa da norma. Assim, o exercício dessas prerrogativas, põe em causa o fundamento axiológico-normativos que todas possuem, "em termos que podem trazer conformidade ou contraditoriedade entre um e outro e, por aí, a admissibilidade genérica da figura do abuso do direito em relação a todas as prerrogativas individuais". ${ }^{101}$

Ademais, o autor ainda pontua que, apesar de o Código Civil português também se referir ao termo "direito", tal como o faz o brasileiro, isso "é, sob este aspecto, coisa de pouca monta, pois é a substância fundamentada e fundamentante que leva ínsita a possibilidade de abuso". ${ }^{102}$

\subsection{Critérios de aferição do abuso do direito no artigo 187 do Código Civil de 2002}

\footnotetext{
${ }^{99}$ CARPENA, Heloísa. O Abuso do direito no código de 2002. p. 440.

${ }^{100}$ CUNHA DE SÁ, Fernando. Abuso do Direito. p. 611-612.

${ }^{101}$ No mesmo sentido de Heloísa Carpena e Fernando Augusto Cunho de Sá, está o entendimento de António Menezes Cordeiro: "O exercício inadmissível, por disfuncionalidade face ao sistema, foi fixado com referência ao direito subjectivo; nessa base surgiu, aliás, a doutrina inicial do abuso do direito. O tratamento típico dos exercícios dito abusivos mostrou que o fenómeno pode ocorrer em situações irredutíveis a direitos subjectivos num sentido estrito: poderes, faculdades, direitos potestativos e outras realidades colocam-se, em certas circunstâncias, perante o sistema, numa sequência tal que a sua actuação, contrariando a boa fé, torna-se, na linguagem do Código Civil, 'ilegítima'. O âmbito da inadmissibilidade de exercício, limitado ao direito subjectivo, numa visão história e nuclear-explicativa, deve ser alargado" (CORDEIRO, António Menezes. Da boa fé no direito civil. 7. reimp. Coimbra: Almedina, 2017, p. 898).

${ }^{102}$ CUNHA DE SÁ, Fernando. Abuso do Direito. p. 612.
} 
Tal como já exposto, o artigo 187 do Código Civil prevê certos limites, que devem ser manifestamente excedidos para que se configure o abuso do direito, sendo eles os impostos (i) pelo seu fim econômico ou social, (ii) pela boa-fé ou (iii) pelos bons costumes.

Passar-se-á, portanto, à análise de cada um desses três limites, mas, antes, cumpre ressaltar que não é necessário que se exceda todos eles para a configuração do abuso, apenas um é necessário, já que o referido artigo prevê uma enumeração alternativa, e não cumulativa. ${ }^{103}$

Nessa linha, ainda, considerando que basta o descumprimento de um desses limites para se configurar o abuso, o artigo 187 indica, a contrario sensu, critérios que devem ser necessariamente seguidos para o exercício regular do direito - o exercício do direito "deve pautar-se pela adequação ao seu fim econômico ou social, à boa-fé e aos bons costumes". ${ }^{104}$

\subsubsection{O fim econômico ou social do direito}

O primeiro dos critérios previstos pelo artigo 187 do Código Civil é o relativo ao fim econômico ou social do direito - ou qualquer outra situação jurídica subjetiva - o qual se investiga se está sendo exercido em abuso.

ANTÓNIO MENEZES CORDEIRO explica que "a função econômica e social do direito tem a ver com a sua configuração real, a apurar através da interpretação" e assevera que "se um direito é atribuído com certo perfil, já não haverá 'direito' quando o titular desrespeite tal norma constitutiva". ${ }^{105}$ Assim, se observa que o fim econômico ou social constitui parte indissociável de um direito, na medida em que expressa a razão pela qual aquele direito foi previsto pelo ordenamento jurídico. ${ }^{106}$

\footnotetext{
${ }^{103}$ MOREIRA, José Carlos Barbosa. Abuso do direito. p. 131. No mesmo sentido: “Antes de se analisar cada um desses três conceitos, impõe esclarecer que para se caracterizar o abuso do direito o titular do direito precisa exceder manifestamente pelo menos um desses limites. Isso significa dizer, em outras palavras, que não é necessário que ultrapasse mais de um cumulativamente, pois se cuida de uma enumeração alternativa" (NANNI, Giovanni Ettore. Abuso do direito. p. 753).

${ }^{104}$ MIRAGEM, Bruno Nubens Barbosa. Abuso do direito. $\mathrm{p} 155$.

${ }^{105}$ CORDEIRO, António Menezes. Tratado de Direito Civil Português, v. I, tomo I. 2. ed. Coimbra: Almedina, 2000, p. 248.

106 MIRAGEM, Bruno Nubens Barbosa. Abuso do direito. p 151.
} 
Dessa forma, a função que deve ser investigada "há de ser aquele regulamento de interesses tendente à produção de efeitos de cada situação jurídica subjetiva, o 'para quê' a justificar a individualização e a proteção da posição jurídica pelo ordenamento". ${ }^{107}$

É nesse sentido que GIOVANNI ETTORE NANNI adverte que os limites impostos pelo fim econômico ou social de um direito não são fáceis de conceituar em termos genéricos, já que a finalidade de cada direito varia, uma vez que a lei, ao regular os mais variados institutos jurídicos, atribui a cada um deles uma finalidade social e econômica própria. ${ }^{108}$

Com isso, a noção de exercício abusivo baseado na função específica de cada situação jurídica permite, ainda, visualizar a fronteira entre abuso e ilícito, já que "enquanto o ilícito decorre de direta desobediência à estrutura das situações jurídicas (não há direito), o abuso se afere em um segundo degrau do controle dessas situações", visto que ele irá ocorrer "se, embora obedecida a estrutura (o titular não excede as prerrogativas que se lhe conferem), a posição jurídica é exercida em finalidade diversa daquela que justifica a sua existência”. ${ }^{109}$

\subsubsection{A boa-fé objetiva}

O segundo critério, a boa-fé objetiva, é, dentre os previstos no artigo 187, talvez o que seja objeto da análise mais profunda por parte da doutrina. ${ }^{110}$ A atuação de acordo com a boa-fé se concretiza "através de deveres de informação e de lealdade, de base legal, que podem surgir em situações diferenciadas, onde as pessoas se relacionem de modo específico". 111

Afirma-se que o Código Civil de 2002 fez referência à boa-fé objetiva em três de seus dispositivos, que correspondem diretamente às três principais

\footnotetext{
${ }^{107}$ SOUZA, Eduardo Nunes de. Abuso do direito. p. 71.

108 NANNI, Giovanni Ettore. Abuso do direito. p. 753.

${ }^{109}$ SOUZA, Eduardo Nunes de. Abuso do direito. p. 71-72.

${ }^{110}$ MIRAGEM, Bruno Nubens Barbosa. Abuso do direito. $\mathrm{p} 151$.

${ }^{111}$ CORDEIRO, António Menezes. Da boa fé no direito civil. p. 648.
} 
funções atribuídas pela doutrina ao princípio, quais sejam, "i) cânone interpretativo dos contratos (art. 113 do Código Civil); ii) parâmetro limitador do exercício de direitos (art. 187 do Código Civil); iii) fonte de deveres anexos dos contratantes (art. 422 do Código Civil)". ${ }^{112}$

Assim, é justamente no abuso do direito que a boa-fé objetiva encontra uma de suas três funções, impedindo ou inadmitindo o exercício de um direito que lhe seja contrário.

No entanto, faz-se necessário cotejar as noções de abuso e de boa-fé, que, segundo assevera ANDERSON SCHREIBER, devem coexistir, ao invés de se anularem, não podendo haver dúvida de que, no ordenamento jurídico brasileiro, a boa-fé funciona como um dos três critérios axiológico-materiais para a verificação do abuso - ou seja, o exercício de um direito será considerado abusivo, sendo assim vedado, ao se verificar ser este contrário à boa-fé objetiva. ${ }^{113}$ Assim, o autor ainda destaca que:

o abuso do direito aparece, ao menos sob este aspecto, como sinônimo de exercício de um direito tornado inadmissível por contrariedade à boa-fé. É certo que, na expressa dicção do artigo 187, o exercício pode ser ainda tornado inadmissível por contrariedade aos bons costumes ou ao fim econômico ou social do direito - e também aí haverá abuso do direito. O abuso do direito é, sob este ângulo, mais amplo que a boa-fé objetiva, porque não apenas impede o exercício de um direito contrário à boa-fé, mas também em outras situações em que o confronto se dá com os bons costumes ou com o fim econômico e social do direito. Sob outro ângulo, contudo, a boa-fé é mais ampla que o abuso, porque não apenas impede o exercício do direito que lhe seja contrário, mas também impõe comportamentos e serve de critério hermenêutico-interpretativo nas relações negociais. Conclui-se, ao menos à luz do direito positivo brasileiro, que a boa-fé objetiva e o abuso do direito são conceitos autônomos, figuras distintas, mas não mutuamente excludentes, círculos secantes que se combinam naquele campo dos comportamentos tornados inadmissíveis (abusivos) por violação ao critério da boa-fé. Entre nós, portanto, é possível falar em abuso do direito por violação à boa-fé, sem que aí se esgotem todas as espécies de abuso, ou todas as funções da boa-fé. ${ }^{114}$

À luz dessas elucidações, fica claro que o abuso do direito e a boa-fé objetiva são conceitos autônomos e distintos, mas que se encontram em um

\footnotetext{
${ }^{112}$ SOUZA, Eduardo Nunes de. Abuso do direito. p. 56.

${ }^{113}$ SCHREIBER, Anderson. A proibição de comportamento contraditório. p. 77-78.

${ }^{114}$ SCHREIBER, Anderson. A proibição de comportamento contraditório. p. 77-78.
} 
substrato comum, que é o do campo dos atos tornados abusivos por violação ao critério da boa-fé.

Ademais, deve-se destacar que a doutrina e jurisprudência têm identificado, com base nos limites impostos pela boa-fé objetiva, uma aplicação progressiva de diversas fórmulas de concretização do abuso do direito, ${ }^{115}$ tais como: a proibição do comportamento contraditório (ou nemo potest venire contra factum proprium), a proibição de alegação da própria torpeza (ou nemo auditur propriam turpitudinem allegans), a suppressio (ou Verwirkung), a surrectio (ou Erwirkung) e a tu quoque.

O venire contra factum proprium é, certamente, uma das mais célebres dessa lista. O comportamento contraditório é abusivo porque é um comportamento que, embora aparentemente lícito, vem a se tornar ilícito, ou inadmissível, justamente porque seu exercício, ao ser examinado em conjunto com uma conduta anterior, afigura-se contrário à confiança despertada em outrem, a revelar, no âmbito normativo, contrariedade à boafé objetiva. ${ }^{116}$

Como bem destaca JUDITH MARTINS-COSTA, para a caracterização da ilicitude decorrente da vedação ao venire contra factum proprium, o fato da contradição é necessário, mas não suficiente, sendo preciso que a segunda conduta venha a frustrar um legítimo investimento de confiança, realizado pela parte que alega a contradição, em razão da primeira conduta realizada (o factum proprium). ${ }^{117}$

A proibição de alegação da própria torpeza, por outro lado, guarda proximidade com o princípio de proibição do comportamento contraditório pelo fato de ambas as figuras impedirem uma conduta posterior, em razão de uma conduta anterior praticada pelo mesmo centro de interesses, bem como pelo fato de haver uma certa contradição no alegar da própria torpeza. Porém, as duas possuem uma clara distinção, na medida que a primeira visa reprimir a torpeza, o dolo, a malícia de quem praticou a conduta anterior, e a segunda,

\footnotetext{
${ }^{115}$ NANNI, Giovanni Ettore. Abuso do direito. p. 755.

${ }^{116}$ SCHREIBER, Anderson. A proibição de comportamento contraditório. p. 79.

${ }^{117}$ MARTINS-COSTA, Judith. A boa-fé no direito privado. p. 616-617.
} 
ao contrário, independe da intenção subjetiva daquele que contradiz sua própria conduta. ${ }^{118}$

Já a figura da suppressio materializa-se quando um direito que, não tendo sido, em certas circunstâncias, exercido durante um determinado período de tempo, não possa mais sê-lo por contraria a boa-fé. ${ }^{119}$ Também é chamada de Verwirkung, e foi consagrada pela jurisprudência alemã para designar a inadmissibilidade no exercício de um direito pelo seu retardamento desleal. ${ }^{120}$

A suppressio guarda íntima relação com o venire contra factum proprium, já que também tem como núcleo uma contradição a um factum proprium, mas este se mostra, em tal caso, como um comportamento omissivo. Na suppressio, a inadmissibilidade do exercício do direito se apresenta como consequência de ter a omissão do titular deste direito gerado a confiança em outrem de que aquele direito não seria mais exercido. O que se tutela é também a confiança no comportamento coerente daquele que se tardou em efetivar o seu direito, tratando-se, assim, de uma subespécie do venire contra factum proprium. ${ }^{121}$

Por outro lado, a suppressio pode vir a ensejar a surrectio (também conhecida pelo termo alemão Erwirkung), já que, tal como explica ANTÓNIO MENEZES CORDEIRO, perante um fenômeno de suppressio, o beneficiário pode se encontrar em uma de duas situações: (i) ao ter se livrado de uma adstrição antes existente, recuperou, nessa área, uma permissão genérica de atuação ou, (ii) tendo conquistado uma vantagem particular, adquiriu uma permissão específica de aproveitamento, ou seja, um direito subjetivo. Assim, a surrectio é utilizada para a constituição de um novo direito subjetivo. $^{122}$

\footnotetext{
${ }^{118}$ SCHREIBER, Anderson. A proibição de comportamento contraditório. p. 115-116.

119 CORDEIRO, António Menezes. Da boa fé no direito civil. p. 797.

120 SCHREIBER, Anderson. A proibição de comportamento contraditório. p. 122.

121 SCHREIBER, Anderson. A proibição de comportamento contraditório. p. 125.

122 CORDEIRO, António Menezes. Da boa fé no direito civil. p. 821.
} 
Por fim, o tu quoque é a expressão consagrada universalmente como modo de designar surpresa, espanto, decepção com a atuação inconsistente de determinada pessoa, e significa, de forma literal, "até tu" ou "também tu". Juridicamente, "é referido como o emprego, desleal, de critérios valorativos diversos para situações substancialmente idênticas", tratando-se "da fórmula jurídica de repressão a que, no vernáculo, se resume como 'dois pesos, duas medidas"'. Desse modo, é comum se encontrar referência ao tu quoque em casos em que uma parte, após violar uma determinada norma, pretende exercer uma posição jurídica que lhe é assegurada por essa mesma norma. ${ }^{123}$

No núcleo do tu quoque, também à semelhança do que ocorre no venire contra factum proprium, há uma ideia de contradição e incoerência, embora mais específica, já que é relacionada à utilização de critérios valorativos diferentes para situação objetivamente muita parecidas ou até idênticas. Assim, também é possível classificá-lo como uma subespécie de venire contra factum proprium. ${ }^{124}$

\subsubsection{Os bons costumes}

O terceiro e último dos limites previstos no artigo 187 do Código Civil é o relativo aos bons costumes. Historicamente, a noção de bons costumes foi consagrada como "elemento voltado para a moral social já consolidada, a partir da qual se realizava um juízo de qualidade sobre essas práticas repetitivas, de modo que se pudesse qualificar os costumes como bons ou maus", de modo que estes últimos seriam "particularmente indesejáveis para a ordem jurídica e social". Assim, "essa sempre foi a tônica do recurso aos bons costumes, especialmente no contexto jurídico brasileiro". ${ }^{25}$

EDUARDO NUNES DE SOUZA chegou a destacar que, na doutrina brasileira contemporânea, limitam-se os autores, em grande medida, a

\footnotetext{
${ }^{123}$ SCHREIBER, Anderson. A proibição de comportamento contraditório. p. 120-121.

${ }^{124}$ SCHREIBER, Anderson. A proibição de comportamento contraditório. p. 122.

${ }^{125}$ CASTRO, Thamis Dalsenter Viveiros de. A função da cláusula de bons costumes no Direito Civil e a teoria tríplice da autonomia privada existencial. Revista Brasileira de Direito Civil-RBDCilvil, Belo Horizonte, v. 14, p. 99-125, out./dez. 2017, p. 112.
} 
anunciarem as dificuldades de concretização da noção de bons costumes que, aludida algumas vezes pelo Código Civil de 2002, “soa particularmente extemporânea em um cenário pós-positivista, no qual os valores juridicamente relevantes se encontram consignados em sede constitucional". ${ }^{126}$

PIETRO PERLINGIERI também corrobora o entendimento dessa dificuldade de concretização da noção ao suscitar que esta é, em geral, definida de acordo com "a concepção de costume de uma determinada sociedade, é noção não a-histórica, mas relativa - muda com o tempo e, por vezes, de lugar para lugar -, genérica, destituída, portanto, de um conteúdo específico e determinado". 127

Por outro lado, BRUNO MIRAGEM ao tentar tecer balizas mais objetivas para a interpretação dos bons costumes, destaca que estes, atualmente, devem ser interpretados "em um sentido geral de adequação e efetividade dos direitos fundamentais e sua proteção nas relações entre particulares (critério axiológico)", e também "como expressão das condutas desejáveis pela maioria social (critério sociológico), quando não contraditórias com os direitos fundamentais e a proteção das minorias". Desse modo, assevera que, tal como estabelece o artigo 187, "apenas esse sentido objetivo e avançado, possuindo uma eficácia geral, de proteção da paz social, dos interesses comuns da sociedade e, em última análise, de estabilidade e de efetividade do direito, é de ser reconhecido". ${ }^{128}$

De outro ângulo, JUDITH MARTINS-COSTA também tenta trazer objetividade ao instituto, suscitando que o que melhor atenderia às finalidades do artigo 187 seria a equiparação da expressão "bons costumes" “às boas práticas cominadas aos diversos setores das atividades profissionais", como as de "boas práticas médicas, de engenharia e de

\footnotetext{
${ }^{126}$ SOUZA, Eduardo Nunes de. Abuso do direito. p. 59-60.

${ }^{127}$ PERLINGIERI, Pietro. O direito civil na legalidade constitucional. p. 442.

${ }^{128}$ MIRAGEM, Bruno Nubens Barbosa. Abuso do direito. p 162.
} 
advocacia, bem como em regras de soft law, ou ainda em 'códigos' de conduta, tais como integrantes da chamada governança corporativa"”. ${ }^{129}$

Porém, com toda essa divergência quanto à definição dos bons costumes, EDUARDO NUNES DE SOUZA chegou a cogitar que "as dificuldades no estudo do tema indica[riam] certa tendência ao desuso deste terceiro parâmetro" aludido no artigo 187, mas que uma "análise mais aprofundada dos bons costumes, no entanto, poderia demonstrar sua utilidade, sobretudo para a concretização de certos interesses existenciais". ${ }^{130}$

Seguindo essa linha, portanto, em recentes estudos sobre o tema, THAMIS DALSENTER VIVEIROS DE CASTRO propôs justamente que a cláusula geral de bons costumes deve operar como instrumento de limitação da autonomia extrapatrimonial:

enquanto a autonomia patrimonial é limitada internamente pela função social e pela boa-fé, como já se disse, a autonomia existencial será ilimitada, desde que o seu exercício não impeça ou implique prejuízos à realização da liberdade alheia - caso em que haverá a incidência dos bons costumes como legítimo instrumento de limitação da liberdade extrapatrimonial. ${ }^{131}$

A autora destaca que a interpretação da cláusula geral de bons costumes deve ser feita à luz da Constituição Federal de 1988, de modo que "agora bons costumes, revestido das qualidades de uma técnica legislativa orientada à abertura do sistema", passaria a estar voltado "também para o futuro, vinculando-se à concretização não mais da moral social pura e simplesmente, mas, especificamente, da moral constitucional". ${ }^{132}$

THAMIS DALSENTER VIVEIROS DE CASTRO ainda propõe aos bons costumes a mesma tripartição de funções atribuídas à boa-fé - de criação de deveres, salvaguarda de direitos e cânone interpretativo -, "só que em direção à autonomia existencial". Isso equivaleria a dizer "que a cláusula de bons

\footnotetext{
${ }^{129}$ MARTINS-COSTA, Judith. A boa-fé no direito privado. p. 614.

${ }^{130}$ SOUZA, Eduardo Nunes de. Abuso do direito. p. 60.

${ }^{131}$ CASTRO, Thamis Dalsenter Viveiros de. A função da cláusula de bons costumes no Direito Civil e a teoria tríplice da autonomia privada existencial. p. 115.

${ }^{132}$ CASTRO, Thamis Dalsenter Viveiros de. A função da cláusula de bons costumes no Direito Civil e a teoria tríplice da autonomia privada existencial. p. 112.
} 
costumes desempenha sobre a autonomia existencial as mesmas três funções que a cláusula de boa-fé exerce sobre a autonomia patrimonial". ${ }^{133}$ Esta parece, assim, a concepção mais adequada de bons costumes à luz da atual configuração do ordenamento jurídico brasileiro.

Sob essa perspectiva, portanto, "considerando a previsão da cláusula geral de bons costumes no artigo 187 do Código Civil", tonou-se "ainda mais evidente a possibilidade do abuso do direito como expressão do exercício disfuncional também no âmbito das relações existenciais". ${ }^{134}$

\subsection{Consequências do ato abusivo}

Por fim, cabe ainda tratar aqui de um ponto em muito pertinente: as consequências do ato praticado em abuso. Quanto ao ponto, CUNHA DE SÁ destaca que a sanção do ato abusivo é variável e deve ser determinada, por consequência, de acordo com o caso, de modo que esta determinação da sanção só deve ser feita "em função e de acordo com as circunstâncias específicas do comportamento concretamente assumido pelo titular do direito". 135

Assim, o autor entende que por vezes terá lugar a reparação natural, nomeadamente através da remoção do que foi feito com abuso do direito e, em outras vezes, será apenas admissível indenização pecuniária. Mas, também suscita que, para além da responsabilidade civil, poderá haver uma diversidade de meios que impedirão que o titular do direito exercido de forma abusiva obtenha ou conserve as vantagens que obteve com a sua conduta, tais como: a nulidade, a anulabilidade, a inoponibilidade ou a rescindibilidade do ato ou negócio jurídico. ${ }^{136}$

\footnotetext{
${ }^{133}$ CASTRO, Thamis Dalsenter Viveiros de. A função da cláusula de bons costumes no Direito Civil e a teoria tríplice da autonomia privada existencial. p. 115.

${ }^{134}$ CASTRO, Thamis Dalsenter Viveiros de. A função da cláusula de bons costumes no Direito Civil e a teoria tríplice da autonomia privada existencial. p. 119.

135 CUNHA DE SÁ, Fernando. Abuso do Direito. p. 647-649.

136 CUNHA DE SÁ, Fernando. Abuso do Direito. p. 647-648. Em sentido semelhante está o entendimento de Jorge Manuel Coutinho de Abreu: "mas o abuso de direito não é apenas fonte de responsabilidade civil (...). Para além de se poder exigir a remoção do que se fez (independentemente de culpa do agente, se esta não for exigida para a remoção do que se fez sem direito), quando o
} 
Já BRUNO MIRAGEM ${ }^{137}$ aponta que, com relação às consequências jurídicas da aplicação do artigo 187 do Código Civil, tem-se que a violação dos limites por ele previstos pode dar causa tanto ao dever de indenizar, que vem referido expressamente no caput do artigo 927 do mesmo Código ${ }^{138}$ nesse caso, sendo cabível, deverá ser dada preferência à reposição natural ${ }^{139}$ (artigo 947, $\mathrm{CC}^{140}$ ) -, quanto determinar outras espécies de sanção do ato abusivo, sempre visando eliminar os efeitos do exercício abusivo do direito ou, quando possível, impedir os danos que por ele possam ser causados.

Ademais, cabe fazer uma importante ressalva de que a responsabilidade civil pelo abuso do direito só terá lugar se deste advier um dano, mas, para a configuração do abuso, o dano não representa, ontologicamente, um pré-requisito ${ }^{141}$ - de modo que o abuso poderá ser caracterizado independentemente de o comportamento abusivo ter gerado dano a outrem. ${ }^{142}$

Quanto a uma possível sistematização dos principais efeitos do exercício abusivo do direito, GIOVANNI ETTORE NANNI ${ }^{143}$ destaca o didático posicionamento de LUIS NIEL PUIG, para quem estes são:

1. despojar de toda eficácia o ato abusivo, neutralizando seus efeitos;

2. complementando o anterior, como medida preventiva, o juiz deve arbitrar o necessário para evitar os efeitos do ato abusivo, podendo ordenar que se cesse o ato ou omissão abusivos;

\footnotetext{
abuso se verifique na prática de negócios jurídicos, haverá, em princípio, nulidade” (ABREU, Jorge Manuel Coutinho de. Do abuso do direito: ensaio de um critério em direito civil e nas deliberações sociais. Coimbra: Almedina, 1999, p. 77).

${ }^{137}$ MIRAGEM, Bruno Nubens Barbosa. Abuso do direito. $\mathrm{p} 183$.

138 “Art. 927. Aquele que, por ato ilícito (arts. 186 e 187), causar dano a outrem, fica obrigado a repará-lo".

${ }^{139}$ NANNI, Giovanni Ettore. Abuso do direito. p. 759.

140 “Art. 947. Se o devedor não puder cumprir a prestação na espécie ajustada, substituir-se-á pelo seu valor, em moeda corrente".

${ }^{141}$ SOUZA, Eduardo Nunes de. Abuso do direito. p. 79.

142 "Se voltarmos os olhos, outra vez, para os textos dos arts. 186 e 187, veremos que apenas no primeiro se encontra alusão ao dano. Para quem pena, como nos parece correto, que os pressupostos do art. 186 não são exigíveis para a caracterização do abuso do direito, esta figura poderá ocorrer sem que o comportamento do agente causo dano a outrem. Dir-se-á que, inexistindo dano, é juridicamente irrelevante que o agente haja exercido o direito de forma irregular, e por conseguinte não há utilidade em considerar abusivo o exercício. Mas é esquecer que o ordenamento muitas vezes admite sanções distintas da obrigação de indenizar" (MOREIRA, José Carlos Barbosa. Abuso do direito. p. 133).

${ }^{143}$ NANNI, Giovanni Ettore. Abuso do direito. p. 760.
} 
3. ainda assim, e segundo as circunstâncias, a reposição ao estado de fato anterior ao ato, o que pode se estender à destruição do que realizado abusivamente;

4. repelir a ação derivada do exercício abusivo de um direito; não-cabimento de toda ação que se funde nele;

5. em casos de danos, sua indenização.

Nessa linha, EDUARDO NunES DE SOUZA ${ }^{144}$ também destaca o posicionamento de JOSSERARD, que dividia as sanções do abuso em três grupos:

i) perdas e danos (sanção pecuniária e reparatória);

ii) medidas judiciais preventivas, que representavam, em geral, o suprimento de manifestações de vontade ou o reconhecimento de invalidades (sanção in natura de cunho inibitório);

iii) recusa de tutela jurídica ao titular da situação exercida abusivamente, que não poderia invocar seu direito como forma de defesa.

No entanto, tal como já se ressalvou, a multiplicidade de possibilidades do exercício abusivo do direito impede uma enumeração mais pormenorizada de sanções in natura. Estas serão definidas "diante das especificidades do caso concreto - apenas à luz do qual, aliás, pode ser verificado o abuso". 145

Diante das considerações feitas ao longo desse capítulo, pode-se perceber a relevância do caso concreto para o estudo do abuso do direito, seja pelas origens jurisprudenciais do instituto, seja pela necessidade de se ter situações palpáveis para que bem se possa especificar tanto a forma pela qual o abuso de determinado direito pode se dar, quanto os meios mais adequados para coibir as consequências desse abuso.

Tendo em vista esse cenário, passar-se-á, portanto, para a terceira parte do presente estudo, na qual será possível concretizar os elementos da teoria do abuso do direito através do direito de preferência do locatário, do qual tratou-se no primeiro capítulo, fazendo-se um importante cotejo com a jurisprudência sobre o tema. Assim, serão abordadas a seguir outras formas, para além das que já foram analisadas no item 1.5, pelas quais a relação

${ }^{144}$ SOUZA, Eduardo Nunes de. Abuso do direito. p. 80.
${ }^{145}$ SOUZA, Eduardo Nunes de. Abuso do direito. p. 81. 
prelatícia no âmbito das locações vem a assumir um caráter patológico, precisamente quando o locatário exerce abusivamente o seu direito de preferência. 


\section{CAPÍTULO 3 - O EXERCíCIO ABUSIVO DO DIREITO DE PREFERÊNCIA DO LOCATÁRIO}

Como bem aponta JUdith MARTINS-CosTA, inexiste "um conteúdo pré-definido pelo legislador do que seja o exercício regular e funcionalmente adequado", de modo que "são as circunstâncias presentes no momento do exercício do direito, liberdade, poder ou faculdade que vão configurar, ou não, a sua admissibilidade", que será definida pela "sua conformidade com o respectivo fim econômico ou social, a boa-fé ou os bons costumes". 146

Dessa forma, faz-se necessário trazer aqui casos concretos, bem como casos hipotéticos, para que seja possível delinear, ainda que minimante e sem a pretensão de esgotar o tema, o que, concretamente, configuraria um exercício regular do direito de preferência e o que configuraria um abuso desse direito.

Tal como já exposto, ANTÓNIO MENEZES CORDEIRO faz severa crítica com relação à multiplicação das previsões legais de direito de preferência no âmbito do ordenamento jurídico português, destacando que representariam "um enorme desperdício de riqueza, com o qual se deve saber lidar, para minorar os seus aspectos negativos". 147

Assim, à luz da advertência feita pelo autor português, busca-se aqui entender algumas situações problemáticas que podem surgir a depender do modo pelo qual exercido o direito de preferência garantido ao locatário pela Lei $\mathrm{n}^{\circ}$ 8.245/1991, para que se possa melhor lidar com esse direito, minorando, assim, os aspectos negativos que dele possam advir e preservar "a manutenção do equilíbrio de interesses do sujeito passivo e do preferente", que é justamente um dos traços característicos da relação prelatícia. ${ }^{148}$

Com efeito, esses dois polos de interesses devem ser resguardados: deve ser garantido ao locatário o seu direito de preferência, mas este só deve

\footnotetext{
${ }^{146}$ MARTINS-COSTA, Judith. A boa-fé no direito privado. p. 612-613.

${ }^{147}$ CORDEIRO, António Menezes. Tratado de Direito Civil Português, v. II, tomo II. p. 485.

${ }^{148}$ LGOW, Carla Wainer Charléo. Direito de Preferência. p. 35.
} 
ser assegurado se exercido de modo regular, o único apto a justificar a restrição que ele impõe ao locador quanto à sua liberdade de contratar e quanto ao seu direito de livre disposição do seu bem.

Como visto, se o locatário, no uso de seu direito de prelação, exceder "manifestamente os limites impostos pelo seu fim econômico ou social, pela boa-fé ou pelos bons costumes", tal como disposto no artigo 187 do Código Civil, não se estará mais na seara do exercício regular desse direito.

\subsection{As possíveis formas de o locatário exercer abusivamente o seu direito de preferência}

Para que se possa indagar sobre as possíveis formas pelas quais o locatário pode vir a exercer o seu direito de preferência de modo a ultrapassar as barreiras do regular e entrar no campo do abuso, antes, se faz necessário rememorar a finalidade a ele inerente e a razão de sua previsão legal.

Tal como já tratado no item 1.2, a Lei no 8.245/1991 tem como um de seus objetivos principais a "fixação do locatário no imóvel"149, de modo que a previsão do direito de preferência no âmbito dessa lei veio com o intuito de buscar a preservação dos laços que o locatário desenvolveu com o imóvel a ele locado, revelando, assim, a sua finalidade social e econômica, de modo a propiciar uma otimização da função social da propriedade. ${ }^{150}$

Nesse sentido, assevera um dos co-autores do projeto de lei da atual Lei de Locações, SYLVIO CAPANEMA DE SOUZA, que não deve haver dúvidas quanto a razão de ser do direito de preferência previsto pelo artigo 27 dessa lei: “a de manter o locatário na posse do imóvel, seja para lhe garantir a moradia ou para continuar a exercer o seu comércio". Assim, seria precisamente este o fim social e econômico do qual se reveste a norma e, por

\footnotetext{
${ }^{149}$ PEREIRA, Caio Mário da Silva. Instituições de Direito Civil, v. III, p. 185.

${ }^{150}$ LGOW, Carla Wainer Charléo. Direito de Preferência, p. 24.
} 
isso, "traduz uma justificada restrição ao direito de o proprietário dispor da coisa". ${ }^{151}$

Com isso, a lei busca evitar que, com a alienação, o locatário tenha que desocupar o imóvel e, assim, dá a ele a oportunidade de passar de possuidor direto a proprietário do bem. Daí se infere que "o instituto da preferência, em princípio, tem natureza pessoal e intransferível", ${ }^{152}$ ou seja, é um direito personalíssimo, ${ }^{153}$ já que busca manter a moradia do locatário, quando se trata de locação residencial, ou preservar o seu fundo de comércio, em se tratando de locação para fins comerciais.

Portanto, se o locatário, ao exercer o seu direito de preferência, se desvia dessa finalidade social e econômica da qual se reveste o seu direito, estará entrando na seara do abuso, exercendo-o de maneira irregular.

Faz-se necessário, diante disso, indagar de que forma os limites impostos pelo fim do direito em questão podem vir a ser excedidos. No âmbito da jurisprudência pátria, porém, são raros os casos em que a questão foi suscitada e a matéria foi debatida. No entanto, o Superior Tribunal de Justiça já se deparou com o tema e teve que enfrentá-lo em um caso bastante emblemático.

Trata-se do caso no qual houve a disputa, iniciada em 2011, pelo prédio localizado no número 4.240 da Avenida Atlântica, no Posto 6 da Praia de Copacabana, no Rio de Janeiro, onde estava instalado, à época, o Hotel Sofitel Rio Palace. O litígio envolveu um valor de cerca de 180 milhões de reais e contou com pareceres jurídicos de GUSTAVO TEPEDINO, EDUARDO

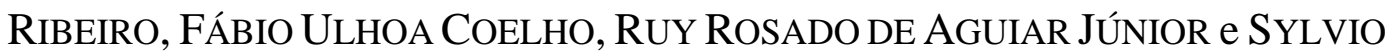
CAPANEMA DE SoUZA. No entanto, apenas neste último foi tratada da questão do abuso do direito de preferência pelo desvio de sua finalidade, tendo,

\footnotetext{
${ }^{151}$ SOUZA, Sylvio Capanema de. Parecer jurídico elaborado por solicitação da consulente BHG S/A - Brazil Hospitality Group, p. 16.

152 SOUZA, Sylvio Capanema de. Parecer jurídico elaborado por solicitação da consulente BHG S/A - Brazil Hospitality Group, p. 15 e 20.

${ }^{153}$ MONTEIRO, Washington; MALUF, Carlos; DA SILVA, Regina. Curso de Direito Civil 5 Direito das Obrigações $2^{a}$ Parte. p. 155; PEREIRA, Caio Mário da Silva. Instituições de Direito Civil, v. III, p. 187; TEPEDINO, Gustavo, BARBOZA, Heloisa Helena; MORAES, Maria Celina Bodin de (Coord.). Código Civil interpretado conforme a Constituição da República. v. 2. p. 189.
} 
inclusive, o autor suscitado serem pioneiras as observações por ele feitas sobre o tema. ${ }^{154}$

Pois bem, a disputa teve origem no âmbito da recuperação judicial da Veplan Hotéis e Turismo Ltda., que era a proprietária do imóvel, tendo o seu pedido de recuperação judicial sido deferido, dentre outras razões, por haver um valioso ativo no patrimônio da Veplan, que era, justamente, o prédio do hotel Sofitel.

As negociações para a venda do imóvel passaram por uma série de percalços, até que a empresa BHG S.A. - Brazil Hospitality Group ofereceu proposta no valor total de $R$ \$ 184 milhões, sendo $R$ \$ 170 milhões à vista; $R$ \$ 10 milhões condicionados à resolução do contrato de locação no prazo de 24 meses e sem o pagamento de qualquer multa à locatária; e $\mathrm{R} \$ 4$ milhões destinados à intermediadora do negócio. A proposta foi aprovada pelos credores, formalizando-se promessa de compra e venda sob condições, mas sua homologação foi rejeitada por decisão do Juízo de primeira instância, que acabou por ser reformada em segunda grau, tendo sido homologado o negócio feito pela recuperanda. ${ }^{155}$

Contra tal negócio, se insurgiu a locatária do imóvel, Nova Riotel Empreendimentos Hoteleiros Ltda., nos autos do processo de recuperação judicial, depositando o valor de $\mathrm{R} \$ 180$ milhões e requerendo o reconhecimento do seu direito de preferência, suscitando, dentre outras questões, que já tinha expressado anteriormente ao Juízo o seu desejo de exercer tal direito e que a Veplan nunca lhe encaminhou notificação para que o exercesse. O direito foi, então, reconhecido por decisão do Juízo da $6^{a}$ Vara Empresarial.

Assim, a BHG interpôs agravo de instrumento contra essa decisão, buscando reformá-la e o recurso veio a ser provido pela $4^{\text {a }}$ Câmara Cível do TJRJ, que entendeu que deveria ser afastado o direito de preferência

\footnotetext{
${ }^{154}$ SOUZA, Sylvio Capanema de. Parecer jurídico elaborado por solicitação da consulente BHG S/A - Brazil Hospitality Group, p. 45.

${ }_{155}$ TJRJ, A.I. no 0063999-73.2010.8.19.0000, $4^{\text {a }}$ C.C., Rel. Des. Paulo Mauricio Pereira, Rio de Janeiro, j. em 06/07/2011.
} 
pretendido pela locatária. ${ }^{156}$ Dentre as razões invocadas pelo acórdão estaria a de que a locatária teria exercido o direito abusivamente por ter desvirtuado a finalidade do instituto, já que teria feito anúncio público de que iria vender o imóvel. Assim, no acórdão destacou-se que:

o direito de preferência tem grande conteúdo social, procurando manter na posse do imóvel o locatário, seja porque lá reside, protegendo sua moradia, seja porque criou no local o seu fundo de comércio, daí que o anúncio público da locatária de que irá alienar o imóvel caracteriza desvio ostensivo da finalidade do instituto da preferência. Como indaga Sylvio Capanema de Souza em seu parecer, "para onde iria o seu fundo empresarial, que o direito de preferência objetiva preservar?", inclusive enquadrando a situação na moldura do abuso de direito (...). ${ }^{157}$

Diante disso, a Nova Riotel interpôs recurso especial contra o referido acórdão e um dos argumentos de que se valeu para justificar a necessidade do provimento do seu recurso foi o de que o Tribunal teria se equivocado ao chegar à conclusão de que o caso se enquadraria na hipótese de abuso do direito, já que assim concluiu por ter entendido que a locatária iria, supostamente, alienar o imóvel depois da sua aquisição, o que configuraria um desvio da finalidade do direito de preferência.

O equívoco estaria na interpretação do documento que teria justificado a conclusão de que a locatária pretendia vender o imóvel, visto que nele se afirmava apenas que este seria "refinanciado" e não que seria vendido a terceiros. A Nova Riotel argumentou que depositou em Juízo, com recursos próprios, os $\mathrm{R} \$ 180$ milhões devidos pelo exercício do seu direito de preferência. Assim, levando em conta a magnitude dos valores envolvidos, seria natural que ela pretendesse, futuramente, se refinanciar, de modo a reduzir o impacto sobre o seu caixa. Isso não significaria, no entanto, que pretendesse alienar o imóvel do hotel que já administrava havia 15 anos naquela época. Ao contrário, pretendia proteger seu fundo de comércio e assegurar sua permanência no local, segundo afirmou.

\footnotetext{
156 TJRJ, A.I. $n^{\text {o }}$ 0000564-57.2012.8.19.0000, 4 ${ }^{\text {a }}$ C.C., Rel. Des. Paulo Mauricio Pereira, Rio de Janeiro, j. em 23.05.2012.

157 TJRJ, A.I. $n^{\circ}$ 0000564-57.2012.8.19.0000, $4^{\text {a }}$ C.C., Rel. Des. Paulo Mauricio Pereira, Rio de Janeiro, j. em 23.05.2012.
} 
Levando em conta tais razões, bem como as demais invocadas pela Nova Riotel em seu recurso especial, a $3^{\text {a }}$ Turma do STJ, por unanimidade, conheceu parcialmente do recurso e the deu provimento para reconhecer o direito de preferência da locatária. Quanto ao ponto do abuso do direito pelo desvio de sua finalidade, o Superior Tribunal entendeu que foi equivocada a qualificação jurídica atribuída à manifestação de vontade externada pela parte, em especial porque o intuito de refinanciar estaria longe de traduzir uma ideia de alienação do bem, se aproximando mais à de um mecanismo para sua preservação. Confira-se:

Pois bem, o Tribunal a quo qualificou a manifestação de vontade da locatária como representativa de sua mera intenção de vender o imóvel. Para tanto, pautou-se apenas pela parte do quanto por ela expressado, que cuidou de destacar.

Penso, com a devida vênia, que, para a correta qualificação jurídica da manifestação de vontade, deve a declaração feita pela parte ser considerada em todos os seus termos. E, dessa forma, constata-se que a ora recorrente manifestou o intento de refinanciar o imóvel mediante contrato de venda e administração.

Segundo o dicionário da língua portuguesa HOUAISS, a palavra refinanciar significa "financiar outra vez; conceder novo empréstimo". E a palavra "financiar" significa "sustentar os gastos (de, com); prover o capital necessário para; custear, bancar".

Nessa seara, foi equivocada a qualificação jurídica atribuída à manifestação de vontade externada pela parte. Primeiro, porque a ação verbal contida na manifestação - refinanciar -, longe de traduzir a ideia de alienação do bem, muito mais se aproxima à de um mecanismo para sua preservação. Segundo, porque o contrato por meio do qual a parte pretenderia perfectibilizar o refinanciamento não é meramente o de venda, mas o de venda e administração.

Se a manifestação de vontade externada pela locatária não é a de simplesmente vender o imóvel, desfazer-se do negócio, como entendeu o Tribunal a quo, mas, ao contrário, é de refinanciá-lo mediante contrato de venda e administração, não há o apontado desvio de finalidade, muito menos abuso de direito. ${ }^{158}$

O caso em questão oferece importantes elementos para o estudo do tema do abuso do direito de preferência em questão. Veja-se que, mesmo que o STJ tenha entendido, por fim, que não houve abuso do direito por parte da locatária Nova Riotel, chegou a tal entendimento apenas porque constatou que a locatária não pretendia vender o imóvel, mas sim garantir a sua permanência nele, mantendo o fundo de comércio que já havido sido por ela

${ }^{158}$ STJ, REsp n ${ }^{0}$ 1.374.643/RJ, $3^{\text {a }}$ Turma, Rel. Min. João Otávio de Noronha, Brasília, j. em 06.05.2014. 
formado havia 15 anos, por meio de um refinanciamento, já que o valor que havia desembolsado era extremamente vultuoso.

Seguindo essa linha, o que se pode daí extrair é que, caso a locatária tivesse, de fato, pretendido simplesmente alienar o bem logo após ter adquirido a sua propriedade, tal fato constituiria uma manifesta violação dos limites impostos pela finalidade a que se presta o seu direito de preferência, consubstanciando um exercício abusivo desse direito, tal como havia entendido o Tribunal de Justiça do Rio de Janeiro.

Com efeito, no parecer jurídico elaborado por SYLVIO CAPANEMA DE SoUZA no âmbito do caso em questão, chegou-se à importante conclusão de que traduz abuso do direito de preferência pelo desvio de sua finalidade o fato de o locatário pretender exercê-lo com o propósito de revender o imóvel, ao invés de preservar o seu estabelecimento ou moradia, o que evidenciaria um mero interesse especulativo e de perseguição de lucro. ${ }^{159}$

CAPANEMA destaca ainda, no parecer, que ao dirimir qualquer conflito que se dê em decorrência do direito de preferência assegurado pelo artigo 27 da Lei de Locações, o julgador deve observar os relevantes propósitos sociais e econômicos de que se reveste a norma, verificando se se está a cumprir a sua finalidade de preservar a moradia ou o fundo de comércio do locatário, vendando-se propósitos meramente especulativos no exercício daquele direito. ${ }^{160}$

Ademais, cabe rememorar que é precisamente essa finalidade social e econômica de preservar os laços do locatário com o imóvel da qual se reveste o seu direito de preferência que fazem com que este tenha um caráter intuito personae, já que considerando os objetivos perseguidos pela sua consagração, "deve entender-se que este direito tem de ser exercido, apenas

\footnotetext{
${ }^{159}$ SOUZA, Sylvio Capanema de. Parecer jurídico elaborado por solicitação da consulente BHG S/A - Brazil Hospitality Group, p. 49.

${ }^{160}$ SOUZA, Sylvio Capanema de. Parecer jurídico elaborado por solicitação da consulente BHG S/A - Brazil Hospitality Group, p. 18.
} 
e só, pelo arrendatário", de modo que um "entendimento contrário conduzirá à inviabilização dos fins em causa". ${ }^{161}$

À luz dessas importantes considerações, cabe ainda dar um passo além, para se tratar de hipótese em que o abuso do direito aqui tratado poderá se dar pela tentativa de desvirtuar o seu caráter intuito personae, que decorre da sua própria finalidade.

Imagine-se um exemplo hipotético no qual Alfa, proprietário de um imóvel comercial alugado a Beta (uma pequena empresa familiar), resolve vender seu imóvel, surgindo um terceiro, Gama, interessado na compra do bem, com o qual Alfa ajusta, de comum acordo, as condições em que a venda deveria se dar. Uma vez feito esse ajuste dos termos do negócio, Alfa expede uma notificação, com aviso de recebimento, a Beta, informando que pretende vender o imóvel a ele locado de acordo com as condições previamente ajustadas com Gama, e indagando se Beta tinha interesse em exercer o seu direito de preferência.

No entanto, mesmo tendo recebido a notificação, Beta deixa transcorrer in albis o seu prazo legal de trinta dias para exercer o direito e não a responde. Como Alfa sabia que Beta era uma empresa pequena, com poucos recursos e com um capital social baixo, já imaginava que esta não viria a exercer o direito de preferência por não ter condições de comprar o imóvel. Assim, entendeu ter sido extinto o direito do locatário, já que sua inércia corresponde à manifestação de vontade em sentido negativo, isto é, de não ter pretensão de exercê-lo. ${ }^{162}$ Dessa forma, Alfa deu seguimento aos trâmites necessários para formalizar a venda do imóvel a Gama, que se prolongaram por alguns meses, findos os quais foi registrado o ato de transferência no registro imobiliário pertinente.

\footnotetext{
${ }^{161}$ GEMAS, Laurinda; PEDROSO, Albertina; JORGE, João Caldeira. Arrendamento urbano, p. 433.

${ }_{162}$ TUCCI, Rogério de Lauria; AZEVEDO, Álvaro Villaça. Tratado da locação predial urbana. v.1, p. 268.
} 
Apesar disso, chegando-se nos últimos dias do prazo de seis meses previsto no artigo 33 da Lei n ${ }^{\circ} 8.245 / 1991,{ }^{163}$ Alfa e Gama são surpreendidos com uma ação contra eles ajuizada por Beta, na qual esta realizou o depósito do valor pelo qual o imóvel havia sido vendido, acrescido das despesas realizadas com a sua transferência, e alegou ter sido violado o seu direito de preferência. Isso porque, segundo afirmou, a comunicação a ela enviada seria ineficaz, visto que não teria os elementos essenciais previstos no parágrafo único do artigo 27 da Lei de Locações, de modo que, por meio daquela ação, estava exercendo coercitivamente o seu direito, requerendo a adjudicação compulsória do imóvel objeto da alienação.

Sem entrar no mérito de se a comunicação para preferência tinha os elementos essenciais para reputá-la eficaz, verifica-se que o depósito realizado nos autos daquela ação não teria sido efetivado pela empresa Beta, mas sim por uma outra empresa, Delta, uma incorporadora imobiliária. Além disso, ao se verificarem as alterações sociais da empresa Beta, observa-se, ainda, que poucos dias após a propositura da ação, a sociedade Delta adquiriu 95\% da sua participação societária, passando a ser sua controladora.

Diante desses fatos, fica claro que quem está pretendendo exercer, de fato, o direito de preferência em questão seria a empresa Delta, enquanto Beta estaria apenas aparentemente buscando exercê-lo, para encobrir aquela que seria a real interessada na aquisição do imóvel, a empresa Delta. Assim, verifica-se que, em uma hipótese como essa, estaria sendo desvirtuado o próprio caráter personalíssimo ${ }^{164}$ do direito de preferência, que é decorrente dos seus fins econômicos e sociais, tal como já exposto, já que quem estaria realmente exercendo o direito seria Delta, encoberta por Beta, que

\footnotetext{
163 “Art. 33. O locatário preterido no seu direito de preferência poderá reclamar do alienante as perdas e danos ou, depositando o preço e demais despesas do ato de transferência, haver para si o imóvel locado, se o requerer no prazo de seis meses, a contar do registro do ato no cartório de imóveis, desde que o contrato de locação esteja averbado pelo menos trinta dias antes da alienação junto à matrícula do imóvel”.

${ }^{164}$ MONTEIRO, Washington; MALUF, Carlos; DA SILVA, Regina. Curso de Direito Civil 5 Direito das Obrigações $2^{a}$ Parte. p. 155; PEREIRA, Caio Mário da Silva. Instituições de Direito Civil, v. III, p. 187; TEPEDINO, Gustavo, BARBOZA, Heloisa Helena; MORAES, Maria Celina Bodin de (Coord.). Código Civil interpretado conforme a Constituição da República. v. 2. p. 189.
} 
provavelmente estaria visando suprir um interesse puramente mercantilista com a operação, buscando obter algum proveito econômico - o que não se coaduna com as razões que inspiram a preferência locatícia.

Tal hipótese, portanto, consistiria em mais uma forma de exercício abusivo do direito de prelação do locatário por violação aos seus fins sociais e econômicos, já que estes o impõe um caráter intuito personae, de modo que somente o locatário pode exercê-lo, devendo as tentativas de desvirtuar esse caráter - como a que ocorreu no exemplo acima - serem enquadradas como abuso do direito.

Por outro lado, deve-se observar que o exemplo em questão também poderia ser enquadrado como um exercício abusivo do direito pela violação aos limites impostos pela boa-fé objetiva, configurando-se hipótese de suppressio, já que é possível entender que foi gerada uma legítima expectativa de que aquele direito não teria sido exercido.

Isso porque diante da comunicação para preferência, a locatária quedou-se inerte, sem demonstrar a intenção inequívoca de exercer o seu direito e suscitar a existência de vícios nos quais teria incorrido a notificação por alguma ausência dos elementos que lhe seriam essenciais, vindo a ajuizar uma ação, muitos meses depois, de maneira desleal e violadora da legítima confiança gerada pelo seu comportamento anterior, ainda que tenha sido ajuizada dentro do prazo decadencial de seis meses, ${ }^{165}$ do qual Alfa e Gama sequer entendiam que Beta faria jus.

\footnotetext{
${ }^{165}$ Quanto ao ponto, Anderson Schreiber assevera que a tutela da confiança que inspira a suppressio (ou Verwirkung) deve prevalecer mesmo que em confronto com prazos prescricionais ou decadenciais: "parece todavia, razoável admitir que, neste confronto com prazos legais (prescricionais ou decadenciais), o valor da segurança jurídica que os inspira ceda em favor da tutela da confiança naquelas hipóteses em que ao simples decurso do tempo se somem comportamento do titular do direito - caso em que o venire contra factum proprium deixa, a rigor, de ser omissivo e adquire sua feição mais comum - ou circunstâncias de fato, imputáveis a ele ou não, que justifiquem uma tutela da boa-fé objetiva independentemente e acima dos prazos fixados em lei, em uma espécie de prescrição de fato. Assim, nas hipóteses de (i) omissão somada a comportamento comissivo inspirador da confiança; ou de (ii) omissão qualificada por circunstâncias que, na ausência de qualquer comportamento do titular, sejam capazes de gerar a confiança de terceiros, pode se tornar aceitável a aplicação do nemo potest venire contra factum proprium, inclusive sob a modalidade de Verwirkung, mesmo na pendência de um prazo legal fixo. A efetiva ponderação, todavia, somente poderá ser feita no caso concreto" (SCHREIBER, Anderson. A proibição de comportamento contraditório. p. 127).
} 
De outro giro, com situação que também envolveu o exercício abusivo do direito de preferência pelo locatário por violação à boa-fé se deparou o Supremo Tribunal de Justiça de Portugal, ao julgar um caso em que foi feita a comunicação para preferência ao locatário e este veio a responde-la, após ter transcorrido o prazo para exercer o seu direito, no sentido de que queria efetivar a sua preferência e comprar o imóvel, manifestando inequivocamente a sua vontade de preferir, sem levantar qualquer tipo de obstáculo à comunicação que lhe fora enviada.

O STJ de Portugal entendeu, naquele caso, que configuraria "uma situação de abuso do direito susceptível de integrar a modalidade do venire contra factum proprium, ${ }^{166}$ a manifestação de exercer o direito de preferência e", de forma subsequente, "vir-se dizer que a comunicação para a preferência não foi feita no estrito cumprimento do preceituado no artigo $416 .^{\circ}$ do C.Civil", ${ }^{167}$ que equivaleria ao parágrafo único do artigo 27 da Lei de Locações brasileira. Confira-se a forma pela qual o acórdão chegou a tal entendimento:

Desta feita, a resposta do Autor à notificação do AI para que exercesse o seu direito de preferência na compra do imóvel, nos sobreditos termos já enunciados, sem que aquele tenha manifestado alguma objecção ao seu teor, nomeadamente, que o mesmo estivesse eivado de irregularidades que o impedissem de compreender o seu conteúdo e alcance, faz criar a convicção de que houve o pleno entendimento, tanto assim que a sua reacção foi positiva, embora tardia, o que consubstancia um factum proprium susceptível de fundar uma situação objectiva de confiança: o Autor, naquelas precisas circunstâncias e mesmo com uma informação deficiente, quis adquirir o prédio.

Por outro lado, subsequentemente, ao ter conhecimento que a sua pretensão era extemporânea, para além de ter criado uma situação de aparente tempestividade daquela resposta, instaura esta acção fundada na omissão de informação relevante para o exercício daquele direito, comportamento este contraditório com aqueloutro, ambos imputáveis ao Autor.

\footnotetext{
${ }^{166} \mathrm{O}$ acórdão ainda destacou a importante função do venire contra factum proprium para corrigir as distorções que podem advir da aplicação meramente formal do direito: "a proibição de comportamento contraditório, embora não constitua uma regra geral de direito civil, mostra-se perspectivada, hoje em dia, como uma cláusula geral de segundo grau, cuja função essencial consiste em corrigir as distorce que existiriam com a aplicação meramente formal do direito. Assim, fazendose apelo a critérios ético-jurídicos, maxime, os resultantes do princípio da confiança, poder-se-á obtempar uma solução que, embora aparentemente conforme à Lei, exceda os limites impostos pela boa fé, porque violadora daquele princípio" (STJ de Portugal, Proc. $\mathrm{n}^{\circ}$ 1518/14.3T8STS.P1.21, $6^{\mathrm{a}}$ Secção, Rel. Min. Ana Paula Boularot, Lisboa, j. em 03.10.2017).

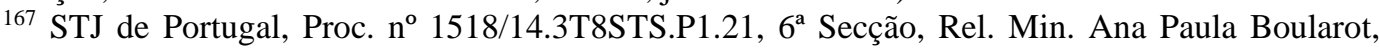
Lisboa, j. em 03.10.2017.
} 
Por seu turno a Ré, aqui Recorrente, atingida com a actuação do Autor adquiriu o prédio de boa fé, confiando na situação que lhe foi apresentada.

Por último, verificamos que o $\mathrm{AI}$ apenas procedeu à venda do imóvel à Recorrente depois de decorrido o prazo concedido ao Autor para exercitar o seu direito de preferência.

A situação objectivamente criada pelo Autor foi de molde a conduzir os intervenientes a inferir da mesma, uma concludência sobre o cabal entendimento das condições negociais que lhe foram transmitidas, de onde, se poder concluir, aliás em consonância com o primeiro grau e o voto vencido aposto à decisão de segundo grau, que ficou precludido pelo decurso do prazo de oito dias aludido no artigo $416^{\circ}, n^{\circ} 2$ do CCivil [equivalente ao prazo de trinta dias previsto pelo art. 28 da Lei de Locações] o direito do Autor a exercer a preferência na compra do prédio de que é arrendatário e que foi objecto da compra e venda efectuada pelo AI à Ré/Recorrente. ${ }^{168}$

Ainda quanto à hipótese de abuso do direito de preferência na modalidade do venire contra factum proprium, cabe aqui destacar o entendimento suscitado por CARLA WAINER CHARLÉO LGOW de que se o locatário, após ter aceitado os termos da comunicação para preferência e ter, assim, exercido o seu direito, desistir posteriormente da compra do imóvel, estaria configurado um venire contra factum proprium e, portanto, um exercício abusivo daquele direito por violação à boa-fé objetiva. ${ }^{169}$

No entanto, deve-se ressalvar que caso se adote o entendimento de que a comunicação para preferir configura uma proposta contratual, de maneira diversa do que entende CARLA LGOW, ${ }^{170}$ na hipótese mencionada acima não teria lugar o venire contra factum proprium.

Isso porque a proposta é um ato vinculativo e, tal como assevera ANTÓNIO MENEZES CORDEIRO, o venire não se verifica quando o primeiro comportamento (que seria o factum proprium) consiste em um ato jurídico vinculante, já que o segundo comportamento, que seria o contraditório ao anterior, consistira em uma violação a um dever específico, de modo que se entraria no campo da responsabilidade contratual e não no do exercício abusivo das posições jurídicas. ${ }^{171}$

\footnotetext{
${ }^{168}$ STJ de Portugal, Proc. no 1518/14.3T8STS.P1.21, 6a Secção, Rel. Min. Ana Paula Boularot, Lisboa, j. em 03.10.2017.

${ }^{169}$ LGOW, Carla Wainer Charléo. Direito de Preferência, p. 110-111.

${ }^{170}$ LGOW, Carla Wainer Charléo. Direito de Preferência, p. 80.

${ }^{171}$ CORDEIRO, António Menezes. Da boa fé no direito civil. p. 746.
} 
Feitas essas considerações, deve-se esclarecer que buscou-se aqui, portanto, demonstrar algumas formas pelas quais o exercício abusivo do direito de preferência do locatário pode se revestir, sem, no entanto, ter-se qualquer pretensão de esgotar o tema, o qual se reconhece ser vasto e poder abarcar diversas outras hipóteses que não foram aqui tratadas.

\subsection{Os possíveis meios de coibir o exercício abusivo do direito de preferência no âmbito das locações}

Uma vez vistas algumas formas pelas quais pode se dar o abuso do direito de prelação no âmbito das locações, cabe, agora, tratar das possíveis sanções que a elas podem ser aplicadas, buscando-se a maneira mais adequada de coibi-las a depender de cada caso.

Tal como exposto no item 2.4 , a sanção do ato abusivo é variável e a sua determinação só deve ser feita "em função e de acordo com as circunstâncias específicas do comportamento concretamente assumido pelo titular do direito", ${ }^{172}$ sempre visando eliminar os efeitos do exercício abusivo do direito ou, quando possível, impedir os danos que por ele possam ser causados. ${ }^{173}$

Com efeito, CUnHA DE SÁ entende que por vezes terá lugar a reparação natural, em especial pela remoção do que foi feito com abuso do direito e, por outras, será apenas admissível indenização pecuniária, mas também destaca que pode haver uma diversidade de meios de coibir o ato abusivo para além da responsabilidade civil, tais como a nulidade, a anulabilidade, a inoponibilidade ou a rescindibilidade do ato ou negócio jurídico, que poderão impedir que o titular do direito exercido de forma abusiva obtenha ou conserve as vantagens advindas do seu ato. ${ }^{174}$

\footnotetext{
172 CUNHA DE SÁ, Fernando. Abuso do Direito. p. 647-649.

${ }^{173}$ MIRAGEM, Bruno Nubens Barbosa. Abuso do direito. p 183.

174 CUNHA DE SÁ, Fernando. Abuso do Direito. p. 647-648. Em sentido semelhante está o entendimento de Jorge Manuel Coutinho de Abreu: "mas o abuso de direito não é apenas fonte de responsabilidade civil (...). Para além de se poder exigir a remoção do que se fez (independentemente de culpa do agente, se esta não for exigida para a remoção do que se fez sem direito), quando o
} 
Quanto ao ponto, vale ainda rememorar o didático posicionamento de LUIS NiEl PUIG, invocado por GiovanNI ETTORE NANNI, ${ }^{175}$ para quem as principais consequências da configuração do exercício abusivo do direito seriam sistematizadas da seguinte forma:

1. despojar de toda eficácia o ato abusivo, neutralizando seus efeitos;

2. complementando o anterior, como medida preventiva, o juiz deve arbitrar o necessário para evitar os efeitos do ato abusivo, podendo ordenar que se cesse o ato ou omissão abusivos;

3. ainda assim, e segundo as circunstâncias, a reposição ao estado de fato anterior ao ato, o que pode se estender à destruição do que realizado abusivamente;

4. repelir a ação derivada do exercício abusivo de um direito; não-cabimento de toda ação que se funde nele;

5. em casos de danos, sua indenização.

Diante dessas breves considerações, deve-se tratar dos possíveis meios de coibir o abuso à luz dos casos concretos e hipotéticos analisados no item anterior.

Quanto ao caso que envolveu o imóvel do hotel Sofitel, caso fosse entendido que a Nova Riotel teria exercido o seu direito de preferência de forma abusiva, o seu ato de depositar o valor da venda do imóvel para exercer o seu direito deveria ser reputado ineficaz. Tal como salientou SYLVIO CAPANEMA, no seu parecer sobre o caso, o abuso afastaria a incidência do direito, de modo a impedir que as consequências da violação do direito fossem reclamadas pela locatária, em especial a pretensão pela desconstituição da compra que havia sido realizada e a adjudicação compulsória do imóvel. ${ }^{176}$

Já com relação ao caso hipotético que envolveu o abuso do direito de preferência pela desconstituição do seu caráter personalíssimo, a principal sanção que poderia ser imposta à locatária Beta seria a de determinar o não cabimento da ação por ela ajuizada com base no seu pretendido direito de

\footnotetext{
abuso se verifique na prática de negócios jurídicos, haverá, em princípio, nulidade" (ABREU, Jorge Manuel Coutinho de. Do abuso do direito. p. 77).

${ }^{175}$ NANNI, Giovanni Ettore. Abuso do direito. p. 760.

${ }^{176}$ SOUZA, Sylvio Capanema de. Parecer jurídico elaborado por solicitação da consulente BHG S/A - Brazil Hospitality Group, p. 46
} 
preferência, julgando-a improcedente. De modo similar como ocorreu com o caso julgado pelo STJ de Portugal, no qual pode-se suscitar, ainda, que foi entendido que a norma que previa os elementos essenciais da comunicação para preferência acabou por ser reputada inoponível para aquele caso por decorrência do comportamento contraditório no qual incorreu o locatário.

Por outro lado, o entendimento suscitado por CARLA LGOW referente à qualificação como venire contra factum proprium da posterior desistência da compra do imóvel pelo locatário que aceitou os termos da comunicação para preferência e, assim, exerceu o seu direito, poderia ter como consequência o desfazimento da conduta contraditória, de modo que o locatário fosse obrigado a contratar com o locador, nos termos que haviam sido ajustados com o terceiro. ${ }^{177}$

Ademais, deve-se destacar, ainda, que ao ser verificada a ocorrência de um dano, será cabível o pagamento de uma indenização, bem como que em casos nos quais seja constatado que o locatário comprou o imóvel a ele locado por meio do exercício abusivo do seu direito de preferência, pode o ato ser reputado ineficaz com relação ao terceiro com quem haviam sido anteriormente ajustados os termos da venda, para que este possa adquirir o imóvel, caso ainda seja este o seu interesse, e, não o sendo, poderia, até mesmo se cogitar da anulação do ato de alienação, caso o antigo locador e proprietário tenha interesse em que o imóvel retorne ao seu patrimônio.

As possibilidades de combate ao ato abusivo são múltiplas e aqui buscou-se apenas delineá-las minimamente, sendo o seu universo certamente muito mais vasto do que o aqui exposto, só podendo ser concretizadas à luz das especificidades de cada situação fática de abuso que se coloque em questão.

Nessa ordem de ideias, conclui-se que tanto as formas pelas quais o locatário pode exercer abusivamente o seu direito de preferência, quanto os meios de coibir o ato abusivo, podem ser os mais variados e o intuito que se teve no presente estudo foi o de tentar concretizar as nuances do abuso do

${ }^{177}$ LGOW, Carla Wainer Charléo. Direito de Preferência, p. 110-111. 
direito de prelação no âmbito das locações, buscando trazer mais materialidade para os limites que não devem ser ultrapassados no exercício desse direito.

Com efeito, o exercício do direito analisado "deve pautar-se pela adequação ao seu fim econômico ou social, à boa-fé e aos bons costumes", ${ }^{178}$ sendo estes os critérios que podem definir a sua forma regular, que é a única apta a justificar a restrição, imposta ao locatário, na sua liberdade de contratar e de dispor do seu imóvel.

${ }^{178}$ MIRAGEM, Bruno Nubens Barbosa. Abuso do direito. p 155. 


\section{CONCLUSÃO}

O direito de preferência conferido pela Lei de Locações ao locatário de imóvel urbano, sem dúvida, se reveste de um inegável caráter social e econômico, visto que tem por finalidade preservar os vínculos que aquele desenvolveu com o imóvel ao lhe conferir a possibilidade de se tornar proprietário do bem, de modo que consiga, assim, preservar a sua moradia ou o seu fundo de comércio.

Para assegurar esse direito a lei confere ao locatário alguns mecanismos de tutela nos casos em que há a sua violação e nos quais a relação prelatícia é acometida por um caráter patológico. No entanto, esse caráter também pode acometer a relação quando o locatário exerce o direito de prelação de forma que não se coaduna com a sua finalidade ou como os valores que o ordenamento pretende com ele realizar, ${ }^{179}$ caracterizando abuso do direito.

Este trabalho buscou, portanto, evidenciar a importância de se analisar a fase patológica que pode vir a acometer a relação prelatícia no âmbito das locações, não apenas sob o enfoque da violação do direito de preferência, mas também sob o do abuso desse direito por parte do locatário, que também pode vir a desvirtuar "a manutenção do equilíbrio de interesses do sujeito passivo e do preferente", uma das características inerentes à relação prelatícia. ${ }^{180}$

Dessa forma, buscou-se trazer à tona algumas formas pelas quais esse abuso pode se dar, no intuito de trazer uma maior materialidade à questão para que se possa lidar com situações semelhantes e delinear as possíveis formas de coibi-las.

Com efeito, tal como destacado por CAPANEMA em seu parecer sobre o tema, ao dirimir qualquer conflito que se dê em decorrência do direito de

\footnotetext{
${ }^{179}$ SCHREIBER, Anderson. A proibição de comportamento contraditório. p. 75.

${ }^{180}$ LGOW, Carla Wainer Charléo. Direito de Preferência. p. 35.
} 
preferência assegurado pelo artigo 27 da Lei de Locações, o julgador deve observar os relevantes propósitos sociais e econômicos de que se reveste a norma, verificando se se está a cumprir a sua finalidade de preservar a moradia ou o fundo de comércio do locatário, vendando-se propósitos meramente especulativos no exercício daquele direito. ${ }^{181}$

O julgador deve atentar-se, assim, para os relevantes limites que tanto a finalidade do direito de preferência, quanto a boa-fé objetiva, ou os bons costumes estabelecem para o seu exercício, de modo a sempre ter esses parâmetros em mente para definir se este está sendo exercido de uma forma regular, que justifique seu amparo pelo ordenamento e a restrição imposta à esfera jurídica do locador.

À luz dessas considerações, busca-se fomentar o debate sobre o tema e abrir os caminhos para o território, ainda pouco explorado, do abuso do direito de preferência nas relações locatícias.

${ }^{181}$ SOUZA, Sylvio Capanema de. Parecer jurídico elaborado por solicitação da consulente BHG S/A - Brazil Hospitality Group, p. 18. 


\section{REFERÊNCIAS BIBLIOGRÁFICAS}

ABREU, Jorge Manuel Coutinho de. Do abuso do direito: ensaio de um critério em direito civil e nas deliberações sociais. Coimbra: Almedina, 1999.

ASCENSÃO, José de Oliveira. A desconstrução do abuso do direito. Revista de Direito do Tribunal de Justiça do Estado do Rio de Janeiro, Rio de Janeiro, n. 66, p. 60-82, jan. 2006.

BARATA, Carlos Lacerda. Da obrigação de preferência: contributo para o estudo do artigo $416^{\circ}$ do Código Civil. Coimbra: Coimbra Editora, 2002.

BUFULIN, Augusto Passamani. Breves notas sobre o direito de preferência na locação de imóveis urbanos: Lei 8.245/1991. Revista de Direito Privado, São Paulo, v. 14, n. 53, p. 101-120., jan./mar. 2013.

CARDOSO, Vladimir Mucury. O abuso do direito na perspectiva civilconstitucional. In: MORAES, Maria Celina Bodin (Coord.). Princípios do direito civil contemporâneo. Rio de Janeiro: Renovar, 2006. p. 61-110.

CARPENA, Heloísa. O Abuso do direito no código de 2002: Relativização de direitos na ótica civil constitucional. In: TEPEDINO, Gustavo (Org.). $O$ Código Civil na Perspectiva Civil-Constitucional. Rio de Janeiro: Renovar, 2013. p. 423-443.

CASTRO, Thamis Dalsenter Viveiros de. A função da cláusula de bons costumes no Direito Civil e a teoria tríplice da autonomia privada existencial. Revista Brasileira de Direito Civil - RBDCilvil, Belo Horizonte, v. 14, p. 99125, out./dez. 2017. 
CORDEIRO, António Menezes. Da boa fé no direito civil. 7. reimp. Coimbra: Almedina, 2017. . Tratado de Direito Civil Português, v. I, tomo I. 2. ed. Coimbra: Almedina, 2000.

. Tratado de Direito Civil Português, v. II, tomo II. Coimbra: Almedina, 2010.

COSTA, Mário Júlio de Almeida. Direito das Obrigações. 8. ed. rev. e aum. Coimbra: Almedina, 2001.

CUNHA DE SÁ, Fernando. Abuso do Direito. Coimbra: Almedina, 2005.

GEMAS, Laurinda; PEDROSO, Albertina; JORGE, João Caldeira. Arrendamento urbano: novo regime anotado e legislação complementar. 3. ed. rev., atual e ampl. Lisboa: Quid Juris, 2009.

GUEDES, Agostinho Cardoso. O Exercício do Direito de Preferência. Teses. Porto: Publicações Universidade Católica, 2006.

LGOW, Carla Wainer Charléo. Direito de Preferência. São Paulo: Atlas, 2013.

LUNA, Everardo da Cunha. Abuso do direito. 2. ed. Rio de Janeiro: Forense, 1988

MAIA, Lívia Barboza. Boa-fé objetiva e abuso do direito nas decisões do Tribunal de Justiça do Rio de Janeiro. In: TERRA, Aline de Miranda Valverde; KONDER, Carlos Nelson; GUEDES, Gisela Sampaio da Cruz. 
Princípios contratuais aplicados: boa-fé, função social e equilíbrio contratual à luz da jurisprudência. Indaiatuba: Foco, 2019. p. 105-121.

MARTINS-COSTA, Judith. A boa-fé no direito privado: critérios para sua aplicação. São Paulo: Marcial Pons, 2015.

MIRANDA, Pontes de. Tratado de Direito Privado. t. XL. 2. ed. Rio de Janeiro: Borsoi, 1962.

MIRAGEM, Bruno Nubens Barbosa. Abuso do direito: ilicitude objetiva e limite ao exercício de prerrogativas jurídicas no Direito Privado. 2. ed. rev., atual. e ampl. São Paulo: Revista dos Tribunais, 2013.

MONTEIRO, Washington; MALUF, Carlos; DA SILVA, Regina. Curso de Direito Civil 5 - Direito das Obrigações $2^{a}$ Parte. 41. ed. São Paulo: Saraiva, 2014

MOREIRA, José Carlos Barbosa. Abuso do direito. Revista Síntese de Direito Civil e Processual Civil, São Paulo, n. 26, p. 125-134, nov./dez. 2003.

NANNI, Giovanni Ettore. Abuso do direito. In: LOTUFO, Renan; NANNI, Giovanni Ettore (Coord.). Teoria geral do direito civil. São Paulo: Atlas, 2008. p. 738-772.

PEREIRA, Caio Mário da Silva. Instituições de Direito Civil, v. III, Contratos. 19. ed. Rio de Janeiro: Forense, 2015.

PERLINGIERI, Pietro. $O$ direito civil na legalidade constitucional. Rio de Janeiro: Renovar, 2008. 
SANTOS, Gildo dos. Locação e despejo: comentários à Lei 8.245/91. 7. ed. rev., ampl. e atual. São Paulo: Revista dos Tribunais, 2011.

SIMÃO, José Fernando. Legislação civil especial: locação e propriedade fiduciária. São Paulo: Atlas, 2007.

SCHREIBER, Anderson. A proibição de comportamento contraditório: tutela da confiança e venire contra factum proprium. 4. ed. rev. e atual. São Paulo: Atlas, 2016.

. Manual de direito civil contemporâneo. São Paulo: Saraiva,

2018 .

SCHULMAN, Ronald. Considerações sobre o direito de preferência na locação urbana. Revista dos Tribunais, São Paulo, v. 73, n. 588, p. 261-265, out. 1984.

SOUZA, Eduardo Nunes de. Abuso do direito: novas perspectivas entre a ilicitude e o merecimento de tutela. Revista Trimestral de Direito Civil, Rio de Janeiro, v. 50, p. 35-91, abr./jun. 2012.

SOUZA, Sylvio Capanema de. A Lei do Inquilinato comentada: artigo por artigo. 11. ed. Rio de Janeiro: Forense, 2019.

Parecer jurídico elaborado por solicitação da consulente BHG S/A - Brazil Hospitality Group, juntado ao processo n⿳000056457.2012.8.19.000. Rio de janeiro, 6 de janeiro de 2012.

STJ de Portugal, Proc. nº 1518/14.3T8STS.P1.21, 6ª Secção, Rel. Min. Ana Paula Boularot, Lisboa, j. em 03.10.2017. 
STJ, EREsp no 1.281.584/SP, Corte Especial, Rel. Min. Benedito Gonçalves, Brasília, j. em 15.05.2019.

STJ, REsp n ${ }^{\circ}$ 1.374.643/RJ, $3^{\text {a }}$ Turma, Rel. Min. João Otávio de Noronha, Brasília, j. em 06.05.2014.

STJ, REsp n ${ }^{\mathrm{o}}$ 1.554.437/SP, $3^{\mathrm{a}}$ Turma, Rel. Min. João Otávio de Noronha, Brasília j. em 02.06.2016.

TEPEDINO, Gustavo, BARBOZA, Heloisa Helena; MORAES, Maria Celina Bodin de (Coord.). Código Civil interpretado conforme a Constituição da República. v. 1. 3. ed. rev. e ampl. Rio de Janeiro: Renovar, 2014. ; Código Civil interpretado conforme a Constituição da República. v. 2. 2. ed. rev. e ampl. Rio de Janeiro: Renovar, 2012.

TJRJ, Ap. Cív. no 0123222- 27.2005.8.19.0001, 3ª C.C., Rel. Des. Helena Candida Lisboa Gaede, Rio de Janeiro, j. em 16.06.2010.

TJRJ, A.I. nº 0063999-73.2010.8.19.0000, 4ª C.C., Rel. Des. Paulo Mauricio Pereira, Rio de Janeiro, j. em 06.07.2011.

TJRJ, A.I. nº 0000564-57.2012.8.19.0000, 4ª C.C., Rel. Des. Paulo Mauricio Pereira, Rio de Janeiro, j. em 23.05.2012.

TJSP, Ap. Cív. nº 1000357- 96.2016.8.26.0132, $25^{\text {a }}$ C.D.P., Rel. Des. Hugo Crepaldi, São Paulo, j. em 29.05.2018. 
TUCCI, Rogério de Lauria; AZEVEDO, Álvaro Villaça. Tratado da locação predial urbana. v.1. São Paulo: Saraiva, 1980.

TWORKOWSKI, Carlos Alberto. A averbação e o registro dos contratos de locação no registro de imóveis: repercussões legais. Revista de Direito Imobiliário. Instituto de Registro Imobiliário do Brasil /Cont. de/RIRI, São Paulo, v. 30, n. 62, p. 15-26., jan. 2007.

VENOSA, Sílvio de Salvo. Direito Civil: Contratos em Espécie. 13. ed. São Paulo: Atlas, 2013.

. Lei do inquilinato comentada: doutrina e prática: Lei $\mathrm{n}^{\circ} 8.245$, de 18-10-1991. 11. ed. São Paulo: Atlas, 2012. 